\title{
Understanding barriers to community participation in HIV and AIDS services: Final report
}

Ashnie Padarath

Catherine Searle

Population Council

Eka Esu-Williams

Population Council

Follow this and additional works at: https://knowledgecommons.popcouncil.org/departments_sbsr-hiv

Part of the Family, Life Course, and Society Commons, Gender and Sexuality Commons, and the International Public Health Commons

How does access to this work benefit you? Let us know!

\section{Recommended Citation}

Padarath, Ashnie, Catherine Searle, and Eka Esu-Williams. 2006. "Understanding barriers to community participation in HIV and AIDS services: Final report." Johannesburg: Population Council. 
Understanding Barriers to Community Participation in HIV and AIDS Services

Final Research Report

Population Council Health Systems Trust

(P Population Council

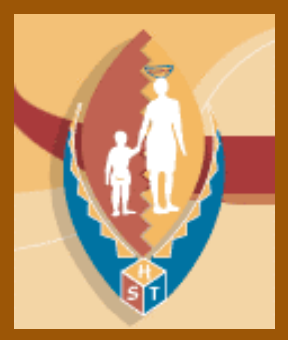
The 


\title{
Understanding Barriers to Community Participation in HIV and AIDS Services
}

\author{
Final Report
}

Ashnie Padarath, Catherine Searle, and Eka Esu-Williams

(2) Population Council

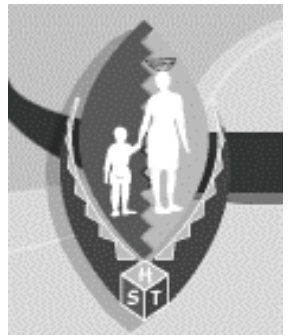

The

A T L A N T I C Philanthropies 


\section{Acknowledgments}

This study was made possible through the financial support of the Atlantic Philanthropies. We are particularly grateful for the many helpful suggestions and comments from Zola Madikizela during the design and development stage. The study was conducted in 2005 by a research team comprising Ashnie Paradath, Zweni Sibiya, Mamra Ntsike, Gael Pennings, and Antoinette Ntuli (Health Systems Trust) and Catherine Searle and Eka Esu-Williams (Population Council, Johannesburg). The support and partnership of officials of the Department of Health and eThekwini Metro in KwaZulu Natal and officials of the Department of Health and Social Welfare in Limpopo are greatly appreciated. This final report was prepared by Ashnie Padarath, Catherine Searle and Eka Esu-Williams. Hena Khan (Population Council, Washington DC) edited the report and Sherry Hutchinson (Population Council, Washington DC) designed and formatted the report. The hospitality and cooperation of the communities in Limpopo and KZN where the field work was conducted are thankfully acknowledged.

For further information please contact:

Population Council

Hurlingham Office Park, 1st Floor, Block D7

Cnr. William Nicol and Republic Road

Hurlingham

192 Dunkeld West, Johannesburg 2196

Tel No: 0114384400

Fax: 0117877371

Website: www.popcouncil.org

\section{(2) Population Council}

The Population Council is an international, non-profit, nongovernmental institution that seeks to improve the well-being and reproductive health of current and future generations around the world and to help achieve a humane, equitable, and sustainable balance between people and resources. The Council conducts biomedical, social science, and public health research and helps build research capacities in developing countries. Established in 1952, the Council is governed by an international board of trustees. Its New York headquarters supports a global network of country offices.

Published in September 2006.

Copyright 2006 The Population Council Inc.

Suggested citation: Padarath, Ashnie, Catherine Searle, and Eka Esu-Williams. 2006. "Understanding barriers to community participation in HIV and AIDS services," Final Report. Johannesburg: Population Council.

This document may be reproduced in whole or in part without permission of the Population Council provided full source citation is given and the reproduction is not for commercial purposes. 


\section{TABLE OF CONTENTS}

Executive Summary 1

$\begin{array}{ll}\text { Introduction } & 6\end{array}$

$\begin{array}{ll}\text { Background } & 6\end{array}$

$\begin{array}{ll}\text { Literature Review } & 7\end{array}$

$\begin{array}{ll}\text { Study Goal and Objectives } & 10\end{array}$

$\begin{array}{ll}\text { Intended Outcomes } & 10\end{array}$

$\begin{array}{ll}\text { Methodology } & 10\end{array}$

$\begin{array}{ll}\text { Results } & 13\end{array}$

$\begin{array}{ll}\text { Cluster One: Barriers at the Community Level } & 13\end{array}$

Cluster Two: Barriers at the Facility Level 26

Cluster Three: Experiences of People Living with HIV and AIDS 31

Cluster Four: Role and Capacity of Community Organisations 42

Conclusions

Recommendations $\quad 53$

Cluster One: Barriers at the Community Level 53

Cluster Two: Barriers at the Facility Level 54

Cluster Three: Experiences of People Living with HIV and AIDS 54

Cluster Four: Role and Capacity of Community Organizations 55

References 56

Appendix: Overview of Study Sites 58 



\section{EXECUTIVE SUMMARY}

In 2003 South Africa announced its intention to rollout what is possibly the largest HIV and AIDS treatment program in the world. Much attention is currently being focused on supply side issues, particularly on the procurement and pricing of drugs. Far less attention has been paid to the equally important issues around the demand for and delivery of treatment, care, and support services. Further, although the role of the community and community organizations is articulated in government policy there has been little active engagement with non-governmental organizations (NGOs) on the development of these roles or on how to encourage community organizations and stakeholders to support and participate in the antiretroviral (ARV) rollout.

This study was conducted to collect data on barriers and challenges to the use of services and on the involvement of community organizations in HIV and AIDS and ARV services for use in the design and implementation of appropriate interventions. The specific objectives of the study, implemented by the Population Council in collaboration with Health Systems Trust and with support from Atlantic

Philanthropies in 2005-2006, were to:

- Improve understanding of the context of the utilization of public health HIV and ARV services, including antiretroviral therapy (ART) and entry points to treatment such as voluntary counselling and testing (VCT).

- Assess the role that communities and community-based organizations (CBOs) can play in the implementation of the government's HIV and AIDS treatment and care plan for the ARV rollout.

\section{Methodology}

For the study, four areas in the provinces of KwaZulu Natal and Limpopo were selected. One urban and one rural community or municipality was chosen in each province for the study. These were:

- Maphumulo municipality in Illembe district in KwaZulu Natal (rural)

- Chesterville in eThekwini (Durban) municipality, KwaZulu Natal (urban)

- Sekhukhune in Makhuduthamaga local municipality in Limpopo (rural)

- Polokwane Municipality in Capricorn district in Limpopo (urban)

Qualitative research methods, specifically focus group discussions and in-depth interviews, were used to generate data on social norms and attitudes as well as to provide insight into the socioeconomic and cultural context of behaviours. The sample frame consisted of health care workers at clinic and hospital level, community workers, people living with HIV, traditional healers, community leaders, NGOs and CBOs in the geographic area, clinic committees, support groups, and community members who were not affiliated to any particular group or organization. A total of 284 people were interviewed.

Permission to conduct the study was obtained from the University of Witwatersrand Ethics Committee. Ethical approval was also received from the Population Council. In addition, it was necessary to obtain permission from the Department of Health to conduct the research in Limpopo and KwaZulu Natal. 


\section{Key Findings}

\section{Communities aware of HIV and AIDS, but need more information}

Communities appeared to be familiar with HIV and AIDS, the burden of the disease and its consequences. Although some basic information on HIV and AIDS was available, frequent references to low levels of access to appropriate information on HIV and AIDS were made. Many people interviewed indicated that the introduction of ARVs was a positive development that has played a key role in containing the virus. However, equally, there were people who viewed ARVs with suspicion and skepticism.

\section{Stigma barrier to HIV and AIDS care, treatment, and prevention}

Stigma, which exists at both household and community levels, is a key barrier to HIV and AIDS care, treatment, and prevention programmes in all research sites, and its impact on social support systems and the psychological well-being of people living with HIV is pervasive. People living with HIV reported difficulty disclosing their status due to fear of stigma and discrimination. Further, testing and initiation and adherence to treatment was often compromised due to fear of discrimination.

\section{Families both stigmatise and support PLHA}

People living with HIV related a wide variety of experiences ranging from rejection and ill treatment to acceptance and support. Family members and outside providers of care and support services generally cared for people living with HIV. Stigma and discrimination appeared to be less prevalent in cases where people had first hand experience of a loved one suffering from HIV and AIDS.

\section{Traditional healers play important role in HIV and AIDS management}

Consultation with traditional healers featured as a common recourse for relief in times of ill health. Most respondents reported seeking assistance from both traditional healers and allopathic medical practitioners. In some sites, cooperation between the two parallel systems existed with traditional healers recommending that clients visit local health centers when an HIV diagnosis was suspected and providing home-based care for HIV patients.

\section{Poverty and dependence huge concerns for communities, people living with HIV}

High levels of poverty and unemployment characterized all sites. Most people reported having experienced food insecurity on a regular basis and basic services (such as water) were often unaffordable or non-existent. Respondents also cited illiteracy as a problem in their communities and social security grants - in particular the disability grant, was often reported as the only source of income in a household.

Disability grants were also a major concern for people living with HIV. Large numbers of people living with HIV not eligible for grants had no other source of income. Using CD4 counts as eligibility criteria for accessing grants precludes many from receiving desperately needed funds and may have several negative effects on treatment and prevention efforts. These include poor nutrition and resultant poor health outcomes for people living with HIV and lack of access to services, which potentially 
increases drop out rates and the number of adherence defaulters. Conversely, some people may use services opportunistically to access grants.

\section{Youth and women particularly vulnerable to HIV}

Despite a plethora of information and messages on prevention of HIV and on reduction of high-risk behaviours, youth are still perceived as engaging in high-risk behaviour. A reluctance to use condoms by youth was reported in all sites. Youth reported difficulty in speaking to their parents about issues related to sex and HIV and AIDS while parents felt that these issues should not be discussed outside the home.

Women experience HIV and AIDS at a multitude of levels. Entrenched patriarchy and poor socioeconomic conditions make women particularly vulnerable to infection. Since they feared being blamed for infecting their partners, some women reported keeping their HIV-positive status secret from their husbands, often out of fear of violence or abandonment.

\section{Numerous barriers to treatment include transport costs}

Most people expressed the view that accessing ARVs is extremely difficult and expensive. Barriers to treatment mentioned included lack of money and food, transport difficulties, having to make too many arduous trips to health facilities, adherence training, poor treatment by health facility staff, inability to apply without a 13-digit bar-coded identity document, long delays between application and receiving treatment, and extensive waiting lists.

\section{Health facilities face staff, space, and equipment shortages}

All sites indicated that human resources shortages were experienced at the health facility level. These shortages referred to nurses, doctors, community health workers, counsellors, and home-based caregivers. Infrastructural constraints included old, dilapidated, or insufficient equipment and a shortage of space.

\section{Adherence and nutritional support for people living with HIV limited}

The introduction of treatment in the public sector has raised concerns about adherence. In order to address adherence and prevent resistance, all people living with HIV receive adherence training prior to starting ARVs. In order to be eligible for treatment, people living with HIV are also required to disclose their status to a treatment supporter, usually a family member, who is also required to attend the training with them to gain information on side effects and their management. All those on treatment reported minor side effects but found them manageable.

Inadequate nutritional support was being provided to people living with HIV with the majority only receiving nutritional advice. Some people living with HIV received nutritional support in the form of supplements or food parcels, which in some cases was limited to the supply of porridge. Little nutritional support beyond counseling and education was available either from government departments or NGOs and CBOs. Many people living with HIV (on and off ARVs) took a wide variety of supplements to boost their immune systems. 


\section{Community involvement with HIV and AIDS issues varied}

There were low levels of broad community involvement in HIV and AIDS issues, although pockets of activism existed in all sites. This activism took the form of support groups, home-based caregivers, fostering, clinic committees, and community health workers. Roles tended to be filled mainly by women on a volunteer basis without remuneration. In all sites, there were signs that HIV and AIDS is starting to find its way onto the agenda of other mainstream community activities, such as in churches, school, and community meetings.

With the exception of a few CBOs predominantly involved in providing home-based care, community members did not report any close links with NGOs working in the area. Respondents in all sites were skeptical about NGOs and suggested that that they did not always work in the best interests of the community, and that they were fragmented and did not work together. At the same time, all sites identified NGOs as having a critical role to play in supporting treatment initiatives and in educating communities on HIV and AIDS.

\section{Recommendations}

Because of high levels of illiteracy and misconceptions, messages contained in posters and pamphlets must be augmented by in-depth discussions about HIV and AIDS at the community level. The use of respected community stakeholders to deliver messages about HIV and AIDS in a wide range of contexts should be explored.

Raising awareness of the existence of stigma in the community, explaining its causes, and the various forms in which it is manifested is crucial to reducing it presence.

Collaboration between traditional healers and Western medical practitioners is increasing and should be further promoted. Traditional healers must receive training and information on HIV and its management, and ways to encourage partnerships between the two health systems need to be explored.

Community-based organizations and NGOs have an important role to play in facilitating access to social security grants at the local level. CBOs and NGOs can act as a bridge between government departments and lobby for speedy processing of applications and the acceptance of alternative means of identification when applicants have difficulty providing the required documentation.

Strategies to address high-risk behaviour among youth must be developed. Forums and groups for youth to discuss their sexuality, among themselves and with their parents and other community members, in a safe non-judgmental environment must be created and sustained. This is especially needed in rural areas where social taboos prevent such discussions. Counseling and rehabilitation services for youth to curb alcohol and substance abuse are also needed.

Poverty alleviation and food security programmes that target women may reduce their dependence on men and subsequent vulnerability to HIV infection. Aggressive, culturally acceptable gender awareness programmes must be carried out at local levels in order to dispel many of the myths that perpetuate gender-based violence and discrimination against women.

Plans must be made to fast track the delivery of ARVs at the primary clinic level. Districts must ensure that NGOs and CBOs are involved in the delivery of treatment at community level. Community level meetings to discuss how best to ensure collaboration between the health service, community, and NGOs, and CBOs are recommended to inform the process of greater involvement by the community and NGOs. 
Efforts are needed to support those caring for HIV infected individuals. Stakeholders recommended that educational activities need to focus on family members as caregivers for those affected by HIV, as this would assist in destigmatising the disease, capacitate caregivers to provide care and support, and increase community support for people living with HIV. Efforts to increase access to treatment will also eventually reduce the burden on caregivers if more HIV-positive people remain well and able to care for themselves.

Given that many people living with HIV live in relative poverty, strategies to improve the nutritional status of individuals are needed. More needs to be done in terms of establishing the efficacy of immune boosters. Strategies to reduce the cost of commercially available supplements may be needed if they are proven efficacious in improving the immune status of people.

Strategies are needed to increase the accessibility and uptake of support group services. Successful models need to be documented and disseminated. Alternative locations for support groups may increase the uptake of services. Similarly, linking support groups to the distribution of food parcels and income-generating activities may also increase their uptake and make them more sustainable. The role of support groups in promoting adherence needs to be explored further.

Steps to facilitate community involvement in HIV and AIDS services must be locally driven. NGOs have a role to play in assisting communities to identify their strengths and available resources as well as areas of need. Resources need to be allocated to drive the process. Transparent and credible mechanisms such as forums for dialogue and discussion between stakeholders and role players must be created at local level. Finally, successful models of community involvement must be disseminated and popularized.

To advocate for greater and effective community involvement in the national ARV program, these recommendations were shared with key local, provincial and national stakeholders at a workshop held in June 2006. In addition further dissemination meetings are planned in the four study sites to refine strategies and to develop appropriate community-based interventions. 


\section{INTRODUCTION}

In 2003 South Africa announced its intention to rollout what is possibly the largest HIV and AIDS treatment program in the world. Much attention is currently being paid to the supply side issues, particularly around the procurement and pricing of drugs. Far less attention has been paid to the equally important issues around the demand for and delivery of treatment, care and support services. Although the role of the community and community organizations is articulated in government policy there has been little active engagement with non-governmental organizations (NGOs) on the development of these roles or on how to encourage community organizations and stakeholders to support and participate in the rollout.

This study was conducted to collect data on barriers and challenges to the use of services and on the involvement of community organizations in HIV and AIDS and antiretroviral (ARV) services for use in the design and implementation of appropriate interventions. The specific objectives of the study, implemented by the Population Council in collaboration with Health Systems Trust and with support from Atlantic Philanthropies in 2005-2006, were to:

- Improve understanding of the context of the utilization of public health HIV and ARV services, including antiretroviral therapy (ART) and entry points to treatment such as voluntary counselling and testing (VCT).

- Assess the role that communities and community-based organizations (CBOs) can play in the implementation of the government's HIV and AIDS treatment and care plan for the ARV rollout.

\section{Background}

In November 2003, the South African Government released its national treatment plan (Mbewu 2003). The initial goal of the plan was for at least one service delivery point in each district to provide AIDS treatment by the end of the first year (2004). This target was subsequently revised to be realized by the end of 2005 .

Treatment sites were identified and inspected under the auspices of the Department of Health (DOH) based on a set of minimum criteria. To meet requirements, in addition to medical considerations, sites needed to have a full range of community support services including counseling, adherence support, community mobilization, home and community-based care, and palliative care. The DOH recognized that key challenges for implementing the treatment plan include: strengthening existing programs that provide entry points to treatment including voluntary counselling and testing (VCT), preventing mother to child transmission (PMTCT), and Tuberculosis (TB) programs, building strong partnerships between health facilities and community support structures, and obtaining good patient information.

It is estimated that approximately 4.84 million people are living with HIV in South Africa (Republic of South Africa 2006). Between 500,000 and 700,000 people are thought to be in need of treatment. In March 2006, a report by the AIDS Law Project found that 110,000 people were receiving ART through the public sector and that a further 90,000 people were receiving it through the private sector (Joint Civil Society Monitoring Forum 2006). Therefore roughly 27 to 38 percent of those in need of treatment are receiving it.

When service use is disaggregated by province, the highest enrollment figures are in Gauteng, the Western Cape and KwaZulu Natal. Overall, far higher numbers of women are accessing treatment than men, likely both because of higher infection rates and higher use of public services including antenatal care. Children make up about 10 percent of all individuals receiving treatment. Only about 
10,000 of the estimated 50,000 children in need of treatment are receiving it (International Treatment Preparedness Coalition 2005).

In 2005, the South African Government's budget for HIV and AIDS (including treatment) was R1.5 billion, and by the end of the year 204 health facilities were providing ART. All 53 health districts have at least one health facility providing treatment and 63 percent of the 252 subdistricts in the country have a rollout site. There are 54 operational sites in KwaZulu Natal's 11 districts, while in Limpopo there are 23 operational sites in the 6 health districts (Republic of South Africa 2006).

Many of the necessary ancillary services and entry points to treatment are provided by communitybased organizations. Home-based care (HBC) services will play a key role in identifying clients in need of ART, and in monitoring adherence and side effects among those already receiving it. TB services using community run directly observed therapy (DOT) programs also need to have strong links to the treatment program. VCT is another key program to provide education on and create demand for treatment. Community mobilization can contribute substantially to the rollout. Successful mobilization ensures adequate support for people living with HIV, combats stigma and discrimination, reduces social isolation, increases adherence, and contributes to the success of community education programs (WHO 2004).

This study sought to understand community barriers to effective participation in HIV and ARV related services. The research was conducted in one urban and one rural site in the provinces of KwaZulu Natal (Chesterville and Maphumulo) and Limpopo (Polokwane and Sekhukhune). Focus group discussions (FGDs) were carried out with a wide range of stakeholders including health facility staff, people living with HIV and AIDS, community leaders, community-based organizations, and community members. A total of 284 people were interviewed.

\section{Literature Review}

Participation by communities is widely argued to be an important component of improving health outcomes and the performance of health systems. There is increasing consensus that involving community groups and representatives, peers, and family members is crucial for the successful largescale roll out of public health programmes. Lessons from TB and river blindness control programmes have shown that systematically engaging these groups can improve treatment outcomes and generate effective local responses (Grubb et al. 2003).

In general it has been observed that an effective partnership between health services and communities depends on an organised demand and contribution from communities that is in keeping with their own perceived priorities. Further, a health system that is capable of responding to community demand and facilitating contribution and matching it with meaningful levels of service delivery is required. Sustained primary health care is also essential for building community participation (Loewenson 2000).

Community empowerment is essential for making active participants rather than passive recipients out of stakeholders. Community participants gain self-awareness, enabling them to confront their problems and put them into perspective. This allows a certain element of health awareness to be developed throughout the community, and in the context of HIV and AIDS, has been shown to decrease AIDS-related stigma and increase HIV testing uptake (Farmer et al. 2001). Empowered communities also have the opportunity to influence their leaders and governments (Muhe 2002) as well as to collaborate with other communities (WHO 2004). This network building allows for community-specific needs to be realized and for the quality of treatment to be maintained and improved. 
With the rapidly changing political and economic climate around the provision of ART in resourcepoor settings, community participation in treatment is essential (International HIV and AIDS Alliance 2002). The growing availability of affordable ARVs may raise public expectations far beyond the current ability to reduce morbidity and mortality rates. In this regard, community preparedness to manage and mitigate unrealistic expectations will be essential, especially as HIV treatment sites will have to refuse ARVs to patients who do not meet minimum eligibility criteria (Van Praag 2002).

Partnerships with affected communities, including people living with HIV and AIDS, will impact how people living with HIV and AIDS understand ART, their health-seeking behaviour, and the acceptability of treatment. Community involvement provides an opportunity to include those living with HIV and AIDS, their families, and communities in the effort to assist people with HIV and AIDS and may help to overcome some of the key obstacles to an effective response, including denial, stigma, and discrimination (Grubb et al. 2003).

Community participation also involves an ongoing process of understanding community beliefs and needs around the drugs, facilitating dialogue, conducting patient education on HIV and AIDS-related treatment, and monitoring and evaluation. It also involves encouraging and facilitating collaboration among various stakeholders, including those outside of the health sector. The potential role of NGOs, CBOs, faith-based organizations, support groups, and community advisory boards in building relevant community-level knowledge, understanding, and skills must be maximized (International HIV/AIDS Alliance 2002).

Results of a community consultation undertaken in Zambia showed that the public perceives the following needs as important:

- They wish to be better informed about ARV treatment and its availability.

- They believe that churches and religious organisations would be useful means of disseminating information and support.

- Communities believe that ARV programmes should parallel TB strategies since they view community involvement in TB DOTS as successful (International HIV/AIDS Alliance 2002).

Other crucial issues include ensuring that community members understand the importance of continuity of supply of ARVs and the ways in which supply interruptions can be prevented. Different methods should be found to include community voices in the planning and management of supplies and cost-sharing mechanisms, and to include community feedback in whatever monitoring and patient support systems are used. This will encourage transparency and community consensus and help to prevent the corruption and mismanagement that are often the cause of interruptions in supplies of vital drugs and materials (International HIV/AIDS Alliance 2002).

There are few incentives for health care workers to work in partnerships and they seldom have the benefits explained to them. Communities, too, may lack the necessary structures, be unfamiliar with medical terms, and be apprehensive about engaging in debate and dialogue with government health professionals. Programmes therefore, must be explicit about the mechanisms and methods that will be used to overcome these obstacles and should include community education and capacity building as a key component of budgeting and planning for HIV and AIDS treatment and care (Grubb et al. 2003).

Community involvement allows those most affected by HIV and AIDS to become active participants in managing their own welfare. This is important on both logistical and ethical levels. Infrastructure and human resources are often lacking in communities where HIV prevalence is high. Moreover, the 1978 Declaration of Alma-Ata proclaims peoples' right and duty to be active participants in their healthcare planning and implementation. Eight years later, the importance of community action towards better health was reiterated in the Ottawa Charter for Health Promotion. 
Phiri et al. (2001) comments that "awareness raising is a fundamental part of the mobilisation process" and that when communities are in a position to "clearly articulate and prioritise a concern, they are more likely to have the motivation to mobilise and work toward the elimination of the problem."

Decentralization can function as a positive means of community mobilization. The Malawi Social Action Fund (MASAF), for example, has facilitated the establishment of community owned projects where project issues such as schools, roads, clinics, bridges, and post offices have been undertaken. Communities contribute 20 percent to the project costs. Still in Malawi, the National Aids Control Programme (NACP) uses participatory methodologies to develop and "create a more comprehensive and informed national policy on AIDS" (Phiri et al. 2001).

The Arogya Sathi programme in India is based on the premise that "if people could monitor the health services that they should rightfully get then they could also play a responsible part in making the public health system work." The initiative, among other things, involved people monitoring the village-level healthcare services. Village health committees would then raise concerns arising out of these monitoring exercises at joint meetings with health personnel (Pitre 2000).

WHO and UNAIDS provide the following recommendations for community involvement (WHO/UNAIDS 2003):

- Use existing community-based projects as infrastructure for carrying out projects (for example: direct observed therapy for tuberculosis and vaccination programs).

- Organize support groups.

- Build community awareness about the importance of ARV adherence.

- Initiate training programs for community members who are expected to be involved.

- Coordinate ART education programs.

- Provide learning resources to community health workers.

- Promote human rights of people living with HIV and AIDS.

- Establish committees comprised of people living with HIV and AIDS and other community representatives to develop, implement, and monitor policies for patient selection, counselling, informed consent, confidentiality, disclosure, discrimination, and support.

- Conduct patient-based evaluation of services.

- Establish links with academic institutions in order to develop research capacity.

Finally, there are a host of legislative imperatives for community participation in South Africa. The White Paper on Transformation of the Health System in South Africa refers to the need for communities to "participate in planning and provision of services." The norms and standards for PHC Framework similarly accentuate the need for community participation. Additionally it has been noted that the there is a strong thread of community participation in the National Health Act. Finally the Operational Plan acknowledges the critical role of community participation in ensuring that the plan is successful and sustainable. 


\section{Study Goal and Objectives}

The goal of this study was to collect data on barriers and challenges to the use of services and on the involvement of community organizations in HIV and AIDS and ARV services for use in the design and implementation of appropriate interventions.

The objectives of this study were to:

- Improve understanding of the context of public health service utilization, including obstacles to the use of HIV and ARV services, including ART and entry points to treatment such as VCT.

- Assess the role that communities and CBOs can play in the implementation of the government's HIV and AIDS treatment and care plan for the ARV rollout.

\section{Intended Outcomes}

\section{Short-term}

- Barriers to service use identified.

- Community stakeholders knowledgeable, energized, and involved in services for people living with HIV and AIDS and prevention activities for the general public.

- Channels of communication and exchange established between communities, organizations, and services.

\section{Medium-term}

- Utilization of the research data to determine appropriate strategies for interventions to overcome barriers to service use in the project sites.

- NGO and health facility services more responsive to the needs of the community.

\section{Long-term}

- Study findings utilized in scale-up or in other districts and provinces to strengthen services and increase uptake of diagnostic, treatment, and care and support services.

- Higher proportions of people obtain VCT, ART, and other care and support services.

- Improved coordination of health facilities and communities in the fight against AIDS.

\section{Methodology}

For the study, four areas in the provinces of KwaZulu Natal and Limpopo were selected. One urban and one rural community or municipality was chosen in each province for the study. These were:

- Maphumulo municipality in Illembe district in KwaZulu Natal (rural)

- Chesterville in eThekwini (Durban) municipality, KwaZulu Natal (urban)

- Sekhukhune in Makhuduthamaga local municipality in Limpopo (rural)

- Polokwane Municipality in Capricorn district in Limpopo (urban) 
Table 1. Summary of HIV prevalence rates in KwaZulu Natal and Limpopo in population sub-groups

\begin{tabular}{lcc}
\hline Population & $\begin{array}{c}\text { KwaZulu Natal } \\
\%\end{array}$ & $\begin{array}{c}\text { Limpopo } \\
\%\end{array}$ \\
\hline ANC clients & 41 & 19 \\
Adults (ages 15-49) & 16 & 12 \\
Youth (ages 15-24) & 8 & 6 \\
\hline
\end{tabular}

Sources: DOH 2004; and Shisana et al. 2005

Qualitative research methods were used to generate data on social norms and attitudes as well as to provide insight into the socioeconomic and cultural context of behaviours. The project sought to generate a rich body of findings from a smaller number of respondents rather than less detailed information from a larger group. The sample frame consisted of health care workers at the clinic and hospital level, community health workers (CHW), people living with HIV, traditional healers, community leaders, NGOs and CBOs in the geographic area, clinic committees, support groups, and community members who were not affiliated to any particular group or organization. A total of 284 people were interviewed. While the findings from the research may not be representative or generalizable, they indicate areas for further exploration and contribute to the development of sitespecific strategies that may have wider applicability in similar contexts.

Table 2. Respondents interviewed

\begin{tabular}{lcccc}
\hline & Maphumulo & Chesterville & Polokwane & Sekhukhune \\
\hline Ordinary community & 20 & 20 & 5 & 24 \\
members & 12 & 11 & 4 & 3 \\
PLHA & 7 & 4 & 8 & 7 \\
Health facility staff & 11 & 6 & 11 & 9 \\
CHW and HBC & 6 & 6 & 3 & 4 \\
Community stakeholders & 4 & 7 & 9 & 12 \\
and leaders & 3 & 2 & 3 & 6 \\
NGOs & 7 & 6 & 5 & - \\
Traditional healers & 2 & 2 & 5 & - \\
Youth & 11 & 6 & 12 & - \\
Men & - & 1 & - & - \\
Women & & & & 65 \\
Caregiver of child on & 83 & 71 & 65 & \\
ARVs & & & & \\
Total interviewed & & &
\end{tabular}

The following research activities were conducted:

- Identification of community leaders and stakeholders in each community.

- Preliminary meeting held with groups representative of community members and service providers to introduce the project.

- 23 FGDs conducted to identify community needs and priorities and social, cultural, and structural determinants/barriers to access to a variety of treatment and related services affecting different groups of service users. 
- 13 FGDs/in-depth interviews conducted with community stakeholders including community leaders, traditional healers, faith healers, and religious leaders to identify community needs and priorities and determinants/barriers to access to a variety of treatment and services.

- 35 FGDs and key informant interviews conducted with program managers and staff, including volunteers, of NGOs, CBOs, FBOs, and AIDS organizations on the services delivered and perceived/potential capacity of the organization.

- Documentation of current community programs relating to the delivery of treatment services.

- Assessment of the capacity of community organizations to represent communities, to participate in structures, and to provide feedback to their constituencies.

- Participatory workshops held in each site to disseminate the findings and to explore the potential role of NGOs, FBOs, and CBOs in the rollout of treatment.

- Strategy development meeting held nationally to discuss implications of the research findings and to map out intervention strategies.

Permission to conduct the study was obtained from the University of Witwatersrand Ethics Committee. Ethical approval was also received from the Population Council. In addition, it was necessary to obtain permission from the Department of Health to conduct the research in Limpopo and KwaZulu Natal. For a detailed overview of the study sites, see appendix 1. 


\section{RESULTS}

The results of this study have been divided into four main clusters: barriers at the community level, barriers at the facility level, experiences of people living with HIV, and the role and capacity of community organizations.

\section{Cluster One: Barriers at the Community Level}

\section{Knowledge of HIV and AIDS}

In general, communities seemed well informed about HIV and AIDS despite some myths and misconceptions. Radio and TV were the major sources of education on issues around HIV and AIDS as well as education given by counsellors in waiting rooms in clinics. For people living with HIV, additional sources of information were support groups, community caregivers, and patient advocates. A range of community stakeholders in all sites made frequent requests for more information on HIV and AIDS.

Education on HIV and its symptoms will be benefit the client and it would improve the rate of compliance among HIV-positive people and their families.

Social worker, Sekhukhune

There is poor communication in terms of disseminating the information on HIV and AIDS to this community. Most of the people are illiterate both adult and young people. They find difficult to use pamphlets and posters. There are many posters here but it doesn't serve the purpose. The only effective way to communicate with the community is to having campaigns with the community and talk about HIV and AIDS.

Deputy chairperson, Maphumulo AIDS Council

We are not well trained in terms of ARVs. But some people in the support groups are taking this treatment. The knowledge we have is very limited; we still need a lot of information and training in order to be able to see our shortfalls and successes.

Regional manager, International NGO, Chesterville

Respondents in KwaZulu Natal indicated that there was a reluctance to accept information on HIV and AIDS from people living in their area because of perceptions that information from outside the area was superior, more credible, and less biased. This distrust of local people is perhaps linked to a long history of political tensions and enmity between major political parties in this province.

In my community they will not listen to me as I'm from the community. People listen to a person from other places then they will trust what that person is saying. To me they can say 'this girl thinks she is better than us because she still fat.'

Community member, Maphumulo

The problem is that people don't trust the information from me if I live in same community with [them].

Social worker, Chesterville

Most respondents acknowledged that the virus is predominantly transmitted through sexual intercourse. Yet despite general awareness of HIV and AIDS, illness in the community was often interpreted as being related to witchcraft and ancestral influence as opposed to HIV and AIDS. This 
was true of both urban and rural areas. Interestingly, none of the HIV-positive respondents interviewed attributed their HIV status to witchcraft or ancestral wrath.

We have problem in rural areas because if you try to tell them about HIV/AIDS they tell you about the past that there were so many illnesses and they were using traditional healers. They don't want to believe that his/her child is HIV-positive or AIDS but they say his/her child has been bewitched.

Community leader, Maphumulo

They usually believe that their relatives are bewitched and not that they are HIV-positive.

Home-based caregiver, Polokwane

There were some differing opinions and belief systems regarding the origin and spread of the disease. These ranged from the belief that HIV is a divinely inflicted disease for non-believers of Christianity to notions that HIV is a creation of the apartheid regime. Other myths include theories that HIV is concealed and spread through free condoms that are distributed by the government, that the HIV virus is found in oranges, that it originated from baboons, and that it is a disease purely confined to the black population. While these comments were not confined to one site, all comments emanated from the rural sites involved in the study.

My attitude changed when she explained that you don't contract HIV through sexual intercourse only but there are many ways of contracting HIV virus. I remembered a verse from the Bible that says if people don't believe in God He will send an incurable disease. I think this is the disease that He was talking about.

ARV class member, Maphumulo

Other reported pathways for transmission of the HIV virus included kissing, taking care of people living with HIV and AIDS, sharing household utensils with them, and eating food that was touched or prepared by an HIV-positive person.

\section{Perceptions of the impact of HIV and AIDS}

Respondents from all sites agreed that HIV and AIDS were widespread and impacted heavily on their communities. Respondents described a feeling of hopelessness towards the disease, which is "killing the nation" and cannot be cured. Some described AIDS as a "mysterious disease" because no cure has been found.

HIV in this community is very high but a lot of people hide their status. The youth is most affected and they die more than older people.

PMTCT patient, Maphumulo

What scares me is that children who were born in 1964, 65, and 66 and onwards are dying in multitudes so we need to have a culture of testing so that there is early detection.

Community leader, Polokwane

The problem is that there is no cure for this disease and we feel that this problem is larger than life.

Clinic committee member, Maphumulo 
Evidence of the fear that HIV and AIDS evokes is aptly illustrated by the following quote from a focus group discussion held in KwaZulu Natal:

We respect this disease we don't want to call it straight by its name.

Woman, Chesterville

\section{Disclosure and community diagnosis}

Community members displayed knowledge of the symptoms of AIDS and reported using an informal system of "diagnosing" people with AIDS in all sites. Commonly used diagnostic criteria included weight loss, fatigue, shingles, diarrhoea, vomiting, rashes, and hair loss.

There is someone that I know who has lost a lot of weight but he does not say that he is HIVpositive. But it's apparent that he might be HIV-positive.

Male, Polokwane

A complex range of other "identifiers" used to confirm a person's positive HIV status existed within communities. For example, being seen with a food parcel was seen as suggesting an HIV-positive status.

When one is HIV-positive they have to eat healthy food and there is a yellow maize meal that is specially made and distributed through the clinic to HIV-positive people. We usually detect someone's HIV status by these food parcels that they carry into their home from the clinic. The majority of community members don't disclose on their own.

Male, Polokwane

The practice of using formula milk instead of breastfeeding was also seen as an identifier of HIV status. As a result of these perceptions, some women resorted to mixed feeding their babies. Visits by home-based caregivers were also seen as a strong indication that someone in the household was infected with HIV. In some cases home-based caregivers were only allowed into homes when patients were terminally ill and there was a sense of inevitable disclosure due to the imminent death of the patient.

The women living in rural areas are the victims of stigma because they live with their mothersin law. If she has a baby and is not breastfeeding they would ask why she is not breastfeeding and they would conclude by saying she is sick (meaning she is HIV-positive). Others end up giving a baby formula and breastfeeding because of the stigma. Most of their husbands are working in big cities.

Social worker, Maphumulo

They usual accept $H B C$ when the patient is unable to walk because then they need assistance with care.

Woman, Polokwane

Given the high levels of stigma and discrimination faced by people living with HIV, disclosure of HIV status is often undertaken in stages. There is often speculation about causes of deaths within the community and disclosure to closer family members (usually caregivers) often takes place just before or after death. 
At the funeral they say 'died after short illness'. When they say that we already know that it's HIV and AIDS that killed the deceased.

Clinic nurse, Polokwane

People prefer to die or tell their parent on their last day that she or he has HIV and AIDS. Others they keep quite until they die. Maybe when a person has died, people would start talk about him or her saying she or he had HIV/AIDS symptoms.

Youth, Maphumulo

\section{Stigma}

HIV and AIDS is a highly stigmatised disease at both the community and household level. Stigma was found to be a key barrier to HIV and AIDS care, treatment and prevention programmes in all research sites and its impact on the social support systems and psychological well-being of people living with HIV was pervasive.

Family members normally discriminate against the one who is sick and has disclosed his/her status. People stop sharing things like utensils with you. Some do not even want to enter your bedroom. You would find people leaving a glass of water and your tablets in the table, when you are too sick to get up and drink by yourself. There was a girl who was found dead and under the bed were a lot of tablets. Which means it was a problem for her to take them and she used to throw them underneath and nobody was monitoring her.

Youth, Chesterville

I know of a case where cruel things happened where a TB/HIV patient was closed indoors and nobody went into that room because they said the individual will infect them. Even when they gave such a person food they opened the door slightly and put the food on the ground. Even windows were closed because they were scared that they would be infected. They even refused when visitors came into the room and they said visitors would depress the patient further.

Youth, Chesterville

At the broad community level, people suspected of being HIV-positive were reported to be subject to scorn and ridicule. Stigma at the household level manifested in both individual rejection and fears of family stigmatization by the community.

There is also a problem for people to hide their status because they fear that people will laugh at them. There are people who are laughing at HIV-positive people.

Faith healer, Chesterville

We are afraid of people with HIV and AIDS we even gossip and laugh at them.

Woman, Polokwane

The stigma associated with HIV was said to originate from the perception that it is contracted from "sleeping around," and that it is considered a dirty, disgraceful, shameful disease. Participants from all sites reported that an HIV-positive person is regarded as sexually promiscuous and immoral.

It's because it's perceived as a sexually transmitted disease. Therefore when we talk about HIV people, we always refer to this as a disease of someone who flirts.

Clinic staff, Sekhukhune 
People fear to disclose as this disease is contracted through sex. People's perception is that people who are infected with the HIV virus are not well behaved.

Clinic committee member, Maphumulo

The reason for that is because the community knows that the only way to get this virus is through sex and that people who get it are 'loose' (abantu abagangile).

Person living with HIV, Maphumulo

Service providers identified the underlying reasons for stigma as a lack of knowledge and information on HIV and AIDS, which enables these perceptions to be expressed and perpetuated.

Stigma is the most serious problem some people don't even want their families to know about their status and these are the very people who are required to support them during adherence training. The result is that these clients drop out and they never return.

NGO leader, Polokwane

We see how people living with AIDS suffer because of stigma, which needs to be removed. Friends and parents of people living with AIDS ignore them because they think they would be infected. When the time goes on we noticed that people start to understand about HIV and AIDS through awareness and education.

Chairperson, local hospice, Chesterville

I think people need to be educated. I think stigma is the cause of lack of information. The people who have information they don't have problem in terms of supporting their sick people.

Social worker, Maphumulo

\section{Confidentiality and disclosure}

In all sites, stigma was also reported to be strongly associated with visiting certain health facilities, like VCT and ARV treatment sites, which can delay individuals finding out their status and initiating treatment. As many health care workers are also community members, people living with HIV reported reluctance to access local health services out of concerns for confidentiality. Many chose to travel long distances (as much as 120 kilometres) to access other health services rather than risk being identified as HIV-positive in their own communities.

The nurses who are working here are gossiping about people who come to the hospital. They even mention a person' name if they are talking. They say we saw so and so at hospital she or he was checking that thing.

ARV class member, Maphumulo

At the same time, stigma appeared to be fuelled by secrecy and non-disclosure. Speculation regarding people's HIV status was a common feature of all sites and disclosure seemed to reverse the cycle of stigma and discrimination at a community level.

At first when I was ill and very thin the community shunned me and they talked a lot behind my back about the fact that I am HIV-positive; but now I am gaining weight and some are beginning to wonder if its true that I am HIV-positive. I tell them that I am HIV-positive and tell them what the right thing to do is in order for HIV not to kill you. People are always asking questions and I think its part of education required in the community. When you disclose your HIV status it's less stressful because people respond positively when you don't hide your status.

Person living with HIV, Sekhukhune 
Some HIV-positive respondents were able to successfully shrug off the mantle of shame surrounding AIDS and displayed a sense of solidarity and activism around their health status.

We need our own nurses and doctors. We need our own hospital where we can be admitted and taken care of. People make you feel in a certain way and you end up discriminating yourself. Now I am the one who knows that I am sick and what to do henceforth.

Support group member, Chesterville

Stigma and discrimination appeared to be less strong in cases where people had experienced someone close to them die of AIDS. Families caring for a sick relative also appeared to be less judgemental towards other people living with HIV.

This gave us a chance to see that HIV and AIDS exist and it's killing because we always heard about it. Now we have seen that is real...this illness is like any other illness. I don't know why people think it is shameful.

ARV patient supporter, Chesterville

The problem is that people don't want to disclose their HIV status because they are afraid that other people in the community will laugh at them. However I disclose about my son's HIV status. I want to show the community that there is nothing wrong with disclosing about the HIV status of your family member. I also want the community to be aware that I can advise them about what to do when one of their children is HIV-positive.

Church minister, Polokwane

Notwithstanding the apparent reversal of stigma and discrimination upon disclosure, people living with HIV were still reluctant to disclose their status, and fear of ramifications that would follow disclosure was a powerful deterrent against revealing one's status. The overall effect of stigma and discrimination was that many people living with HIV saw their social network collapsing and felt condemned to a life of secrecy and isolation. One rural site reported incidents of suicide due to HIV status.

Young people do commit suicide in this community. Most of them suspected that they were HIVpositive.

Youth, Maphumulo

In one urban site, interviewees said that people who recently discovered that they are infected with HIV deliberately infected other people.

When some people find out that they are positive, they say they want to die with a lot of people, and they go around infecting other people intentionally.

Woman, Chesterville

\section{Health seeking behaviour}

Successful treatment and care initiatives depend largely on the health seeking behaviour of people. How disease is perceived and interpreted, as well as acceptance of health promotion messages from credible sources, impacts on decisions to seek and access treatment.

\section{Patterns of consultation}

Consultation with traditional healers featured as a common recourse for relief in times of ill health. The term "traditional healers" was used broadly and encompassed faith healers (Izangomas) and herbalists (inyangas). Most interviewees reported seeking assistance from both traditional healers and 
allopathic medical practitioners although the order of consultation varied between sites. In general, respondents in urban sites tended to visit allopathic healers at their local clinics, before seeking the help of traditional healers. Patterns of consultation also varied according to age groups, with younger respondents preferring local health services to traditional healers. Traditional healers were often used as a supplement to western medicine, with the latter being resorted to after there was no improvement from traditional medicine.

In this community most people are consulting traditional healers. I think people need to be educated about health because they consult traditional healers first. They consult hospitals when their situation is worse which make very difficult for doctors and nurses to help.

Patient advocate, Maphumulo

One respondent indicated that she was using a traditional healer only until she could get enough money to take her child to the clinic.

I intend to take her [the child] as soon as I have money for transport. I use traditional medicine in the meantime.

Woman on ARVs, Maphumulo

Reasons for using traditional healers included that they were based in the community, were culturally acceptable, easily accessible, would not make an HIV diagnosis, and were more reliable. Other reasons for use of traditional healers included beliefs that they could reverse of spells or bewitchment, which lead to infection with the HIV virus.

The reason for them to consult traditional healers is that traditional healers are in the community compared to the money they spend on transport to hospital. There is mobile clinic, which comes once a month, and it does not come if it is raining. It is something you cannot rely on.

Community members, Maphumulo

There are these traditional healers who say they cure HIV/AIDS and people believe those stories.

Church leader, Chesterville

There are people who are HIV-positive who consult traditional healers. These people who are consulting traditional healers are those who are sick and don't want to accept that they are HIV-positive.

Person living with HIV, Maphumulo

The worse issue in these communities is of Isangoma. The Isangoma don't tell people to go to hospital but they cause trouble among neighbours by saying someone is bewitching you.

Community leader, Maphumulo

Some younger respondents eschewed the use of traditional healers, describing them as expensive or incapable of making accurate diagnoses due to the lack of appropriate diagnostic technology.

Traditional healers are so expensive. They charge R200 for small thing.

Youth, Maphumulo 
Traditional healers can't check if you are HIV-positive or not. Only a hospital can do that. People go to traditional healers with a hope that they can stop HIV virus for a time being. Even though traditional healers works but they don't know how to see if a person has HIV or not. I can't believe the person who guesses what I'm suffering from because they don't use anything to check what a person suffering from.

ARV class, Maphumulo

\section{Impact of traditional treatment}

Reports of the effects of treatment prescribed by traditional healers were shared in all sites, with Limpopo Province displaying more awareness of the possible dangers of traditional medicine. The most common form of treatment recommended by traditional healers was the use of enemas, which can have a severe impact on already compromised immune systems.

I went to traditional healers when my illness started. I had no information that time.

Traditional healers use different medication but their medication that use enemas makes you weak because it causes a running tummy. I can't use that medication because I'm already weak.

Person living with HIV, Chesterville

They start with traditional healers who induce vomiting and diarrhoea and thus further weakening the HIV-positive person, as people in this condition are not supposed to vomit and have diarrhea. They also cover the patient's body and use traditional incense (Ho arubetsa) to the patient living with AIDS. This wastes a lot of time, as this type of treatment does not address the problem of HIV.

Church leader, Polokwane

Promises of cures and a refusal to accept conventional theories and management of HIV and AIDS (despite training) by some traditional healers destabilized awareness raising and information sharing initiatives and could even reverse the gains made by AIDS activists.

We were tanght about how this disease is treated in the western way as we as traditional healers have a different way of dealing with this disease... what happens is that a man and a woman's bladder get infected and then they develop sores in their private parts resulting in a flow. What we do is that we give medication to take out the dirt. If dirt does not go out it creates sores.

Traditional healer, Polokwane

\section{Cooperation between traditional and western practitioners}

The apparent tension between western and traditional practitioners was well managed in some sites where traditional healers organized themselves into formal groupings and were responsible for providing training (in collaboration with the local DOH) on the management of HIV and AIDS.

Training of traditional healers has been successful and is still ongoing. There is more understanding about issues related to HIV/AIDS. The perception among traditional healers that they can heal HIVIAIDS does not exist anymore because of lessons obtained from the Department of Health.

Traditional Healers Association, Polokwane

The constitution of a formal organization of traditional healers in one site has had the effect of regulating the profession including a peer review mechanism, structured training sessions (e.g. how to 
carry out sterile incisions, use of gloves), and greater awareness of HIV and AIDS and its management.

In some sites a system of cooperation between the two parallel systems evolved with traditional healers recommending that clients visit local health centres when an HIV diagnosis was suspected and providing home-based care for HIV patients.

We were taught about AIDS prevention and signs of HIV we are now aware that people sometimes have hallucinations when they are HIV-positive nowadays we don't interpret hallucinations as ancestral visitations we refer people to the clinic to be tested for HIV when they present with hallucinations.

Traditional healer, Sekhukhune

The willingness to work with alternative systems of medicine was expressed by western medical practitioners, albeit less frequently.

Traditional healers and faith healers must be trained as counselors and have HIV test kits so that they could help those people who are not willing to go to hospitals.

Community leader, Maphumulo

This is the main problem that we sometimes have where medical practitioners refuse to work with us and refer us to the clinic. We still have to work on being accepted by some of the western doctors, as they don't recognize us. The training that we are receiving is supposed to assist us to be accepted by the western practitioners.

Traditional healer, Sekhukhune

\section{Community knowledge and perception of ARVs}

A wide and varying range of knowledge and perceptions of ARVs existed in all sites. Levels of knowledge tended to be higher in KwaZulu Natal, particularly in urban Chesterville, than in the rural areas. Traditional healers displayed varying degrees of knowledge of the drugs, and NGOs indicated having the most information about ARVs. In general, while most people had heard of ARVs, their information was superficial and gleaned mostly through anecdotal evidence. However, people on ARVs had high levels of knowledge about the treatment and had in some cases played a role in changing community perceptions of the drugs.

ARVs are a new thing in our community so I would safely say a lot of information still needs to be given to the community about ARVs. As even us as leaders are vague and don't have enough knowledge about ARVs. However we don't doubt the fact that ARVs are very effective.

Community leader, Sekhukhune

I think the issue of ARVs is an issue for everybody because even the community does not have information about ARVs. They only know about ARVs when they visit hospitals.

Chairperson, Support group, Chesterville

I can say maybe the amount of people who know about ARVs is 20 percent. Most of the people are illiterate.... They find difficult to use pamphlets and posters.... The only effective way to communicate with the community is to having campaigns with the community and talk about HIV and AIDS.

Deputy chairperson of Municipality AIDS Committee, Maphumulo 
Many people interviewed indicated that the introduction of ARVs were a positive development and that they play a key role in containing HIV. Equally, however, there were people who viewed ARVs with suspicion and skepticism.

Well I have seen people walk after being severely weak. It's fortunate that I am also a faith healer so people confide in me and I see their health improve when they are on ARVS. ARVS improve the lives of people and therefore they are able to live longer that is why I would recommend them to be used.

Community leader, Maphumulo

I have a cousin who was very sick and she went on ARVs. She is now so healthy that if you compare her to me you would think I am the one who is ill because she looks much healthier than me.

Community leader, Sekhukhune

We heard that ARVs are poisoned because they have side effects and they made people ill.... We heard that it causes problem but at the same time we see people improving after using ARV treatment.

NGO, Chesterville

Most of them believe that ARVs are killing people. They think that once you start ARVs you will die very soon.

Member of youth NGO, Maphumulo

The general sentiment expressed by respondents was that HIV-positive pregnant women were given preferential treatment by the health system and were able to access ARVs much faster than others. Additionally, testing through antenatal clinics was a frequently cited as a method through which HIVpositive women learned of their status.

There was a study that was conducted in local clinic but it was focused on pregnant women. It was not helping the community because a person needs to be pregnant so that she will get help. The people who are HIV-positive who are not pregnant are tempted to fall pregnant in order to qualify to this programme of pregnant women.

Chairperson support NGO, Chesterville

Another thing I have noticed is that it is much easier for pregnant women to get access, not those who decided to test for themselves.

Support group member, Chesterville

\section{Socioeconomic factors affecting uptake}

High levels of poverty and unemployment characterized all sites. Most people reported experiencing food insecurity on a regular basis and unaffordable or non-existent basic services (such as water). Respondents also cited illiteracy as a problem in their communities.

Our problem is HIV/AIDS...we also have problem of employment most of people here are not working. Another problem is information about how to access health facilities. Other people stay at home if they are sick because they don't have money. They also don't know that clinic is free of charge. Others they don't know that you can go to hospital even though you don't have money. Others say they don't know that they can phone the ambulance if their family members are sick. People they just think of transport money and ending not get help.

Community member, Maphumulo 
We also have problem of poverty in this community, as many people are not working. Many people are sick and they don't have money to go to clinic or hospital. There is no transport and there is no money.

Woman, Maphumulo

There is a lot of poverty amongst our people and PLHA are no exceptions. Very often their nutritional status is undermined. Food parcels assist for a while but the food has to cater for all members of the family resulting in depletion of food long before the next ration is supplied. Caregiver and person living with HIV, Polokwane

In Limpopo, a clinic garden was being maintained by community members and served as an important site of nutritional assistance to community members. However, this initiative proved to be an exception, as most respondents described their overwhelming poverty.

The MEC for health has encouraged us in clinics to have clinic gardens. We take vegetables from the clinic and try to cook for these people. But sometimes our clinic gardens don't have enough vegetables because of drought.

Church community group, Polokwane

\section{Access to social security}

Access to social security featured as a significant problem in all sites. The requirement that an applicant wishing to access a social grant must be in receipt of a 13-digit identity document caused much hardship to applicants. Many respondents described their experiences in trying to access identity documents from the Department of Home Affairs and time consuming, expensive, and protracted.

What I have noticed is that adult people who apply for ID books don't get their ID's. They apply more than five times and they don't get it. If we ask Home Affairs why these people don't get their documents they say they don't know.

Youth leader, Maphumulo

People don't have grants and old people are left with children to look after and very little money to use in looking after them.

Person living with HIV, Maphumulo

When we apply for the grants sometimes we are not successful. Our parents only receive pension, which is not enough to support us and our children. Now we find ourselves being burdens to our parents.

Support group member, Chesterville

Some respondents have reported borrowing money from informal moneylenders in anticipation of receiving a social grant.

I go to moneylenders because there is nobody to help me...the interest on $R 100$ is $R 40$ but they charge different interest. Others they charge R50 as interest for a loan of R100.

Person living with HIV, Chesterville

\section{Youth and HIV}

There was general consensus that youth were most severely affected by HIV and AIDS. Given the high prevalence of HIV in this age group, and the resources and focus directed towards this target 
audience, the researchers sought to understand their views on prevention and treatment and to ascertain whether they faced any particular barriers to accessing health services.

\section{Reaching youth}

In all sites, youth appeared to have a limited ability to exercise protective practices and access reproductive health service services. Despite a plethora of information and messages on prevention of $\mathrm{HIV}$ and on reduction of high-risk behaviour, the research indicates that there has been limited acceptance and internalization of these messages.

A reluctance to use condoms by youth was reported in all sites. Reasons include embarrassment to ask for condoms, lack of information on how to use them, reduced sensation upon use of condoms, and women refusing to use condoms in order to become pregnant to access the child support grant.

They feel ashamed to take condoms from us as we are working in this community.

NGO staff, Maphumulo

Young people die more than elderly people these days. We bury young people every week. What is worse is that when we discuss issues of health they are just not interested and they don't listen.

Reverend, Polokwane

They take it very lightly and they laugh when they discuss the issue of AIDS. When condoms are discussed they say using a condom is similar to eating a banana with its peels or a sweet with its cover and the whole issue becomes a big joke. They just continue with unsafe sex.

Youth, Polokwane

\section{Attitudes towards sex}

Focus group discussions with youth revealed casual attitudes to sex and high-risk behaviour. Alcohol and drug abuse appeared to be common in all sites, which were exacerbated by fears of being HIVpositive.

When we teach about HIV in schools, a lot of parents come to us and they complain that we are discussing sexual issues with their children and they say they don't want their children to discuss sexual issues with anybody.

Clinic sister, Sekhukhune

We know how they work but the problem is that when young people are drunk they don't use the condoms even if they have them.... Parties and drinking, going to shebeens, because people get exposed to rape in such situations and they forget to use condoms and youth actively engage in all the activities mentioned.

Youth, Polokwane

Even in cases where interviewees were aware of the role of unprotected sex in spreading the disease, some youth expressed disregard for practicing safe sex.

I came through sex and I will die through it.

Informal youth leader, Chesterville

\section{Relationship with parents}

Youth in all sites reported being unable or unwilling to talk to their parents about sex and felt that they would be stigmatised for engaging in pre-marital sex. They also reported feeling unsupported by their parents and felt that they were not able to trust them with their HIV status. 
You may find young people talk about HIV and AIDS but they never been told by their parents about HIV and AIDS.... Adult people haven't accepted the problem of HIV and AIDS in this community. They are the one who gossip if they suspect that someone has AIDS.

Youth, Maphumulo

It is not easy for a young person to tell their parents if she or he has AIDS.

Youth, Chesterville

The proliferation of a "western" way of living (alcohol, drugs, materialism, and casual sex) together with the breakdown and demise of traditional norms (abstinence, virginity testing, and thigh sex) and early sexual debut were considered to be strong contributing factors to the spread of HIV among older respondents in all sites.

There was virginity testing but now this is not happening. There was also thigh sex, which is no longer happening... people believe that the behaviour of people was influenced by western styles. Now in our communities young girls have love affairs when they are very young.

Community leader, Maphumulo

The youth here in South Africa behave like Americans. South Africa...is westernized. All these drugs make them sexually active after they have used them.

NGO leader Chesterville.

\section{Gender and HIV}

Women experience the epidemic differently from men and despite appearing to access health services more than men, bear a disproportionate burden of the consequences of HIV and AIDS. Entrenched patriarchy and poor socioeconomic conditions make them particularly vulnerable to infection. Transactional sex, often as a result of poverty, implies that women do not have the power to negotiate the use of condoms with partners. Gender-based violence contributes to the spread of the epidemic.

Women experience HIV and AIDS at a multitude of levels. Apart from their own vulnerability to infection, they are also responsible for guarding against mother to child transmission, caring for people living with HIV, and acting as primary caregivers for children whose parents have died of AIDS.

\section{Vulnerability to infection}

Women are often blamed for infecting their partners and some women reported keeping their HIVpositive status secret from their husbands.

But it's always the woman who is blamed even if she gets the disease from her husband. The man is never blamed. We have problems in this area as we are always blamed.

Woman, Polokwane

It's more of a problem for women to come back and tell their husbands that I went and tested positive to the HIV test; people get beaten up.

NGO manager, Chesterville

Male migrant workers and polygamy were also cited as contributors of the epidemic. In some sites, sexual prowess and masculinity were equated with having multiple partners and women who were raped were said to have provoked or deserved the attack. In one site, respondents indicated that the myth that sex with a virgin or a child cures HIV and AIDS still prevailed in some quarters of the community. 
Most of the households are headed by women here and you will find that that woman is working in the factory maybe she has four children and she couldn't afford all these children....That girl will start involving in love affairs and the boy will start doing bad things because they want to get fast money.

Youth, Chesterville

There is a popular belief that a HIV-positive man gets cured when they sleep with a small child so that's the reason why they rape small children.

Woman Polokwane

Poverty also seems to be a problem as when a man who provides for a partner and refuses to use a condom. She just has to oblige and not use a condom because she wants money or to be provided for.

Male, Polokwane

I have seen a case where different men everyday pick one girl at $4.00 \mathrm{pm}$. The girl sleeps during the day and starts to bath and go out at $4.00 \mathrm{pm}$ everyday with a different man. These are the type of things that spread HIV/AIDS.

Male, Polokwane

The breadwinners normally work in the city and they collect all the infections, whether HIV or STI. They go there and spread it.

Clinic staff, Chesterville

\section{Use of services}

Women tended to use the health system more than men and showed greater interest in testing and prevention. Uptake of VCT, particularly among pregnant women seemed linked to information received in antenatal classes. There was also a perception that pregnant women were fast tracked for treatment and more able to access treatment.

$V C T$ is more successful among pregnant women, as they want to protect their unborn children from infection. This group in the community responds better to counseling.

Clinic sister, Sekhukhune

The people who are HIV-positive who are not pregnant are tempted to fall pregnant in order to qualify to this programme of pregnant women.

Chairperson, Support group, Chesterville

We can't talk to guys about HIV AND AIDS, particular being HIV-positive. They don't want to hear such things. The people who listen if you talk about HIV AND AIDS are girls.

Person living with HIV, Maphumulo

\section{Cluster Two: Barriers at the Facility Level}

This section sets out the main barriers that are perceived to exist at facility level with impacts on access to and uptake of services. 


\section{Access to treatment}

Most people uniformly expressed the view that accessing ARVs was extremely difficult and expensive. People perceived of the application and qualifying process as riddled with barriers. Such barriers included lack of money and food, having to make too many trips to health facilities for CD4 tests, being too ill to make arduous trips to health facilities, the inability to apply without a 13 digit bar-coded identity document, long delays between application and receiving treatment, and extensive waiting lists.

Clients wait too long.... Let's say today it's the $16^{\text {th }}$ of Nov. The appointment for drawing of blood for the CD4 count will be scheduled for the $28^{\text {th }}$ of December. After which a client waits for two weeks for the results. They might want the $2^{\text {nd }}$ test for reconfirmation of results, which could take another two weeks. After which the adherence training takes place. In the meantime the client's health usually deteriorates and it's very expensive to travel from the village to the hospital. This usually results in dropouts due to frustrations and mere poverty.

NGO staff member, Polokwane

She went there for a CD4 count. When she was supposed to collect the results she was very sick and her sister went there to collect the results but they refused to give her the results. They said they wanted her to collect her results. She died after that because she was unable to walk. We had no transport to help her to collect her results.

NGO staff member, Chesterville

There is little follow up of patients who are referred for services. Reasons for this follow up include lack of enough resources, lack of systems and one-way referral processes.

We check the patient's HIV status and if positive we refer them to the hospital for a CD4 count. They don't come back to give us a report after being referred. Some come from very far and they default because they come from far and the staff in the clinic is too small to follow up on people from the community. There is no staff that refers patients from the community to the clinic because of shortage of community health workers.

Health facility staff, Maphumulo

\section{Transport}

Most HIV-positive respondents reported that the travelling costs associated with accessing treatment and care were prohibitive. Transport related barriers to accessing health services were mentioned at both the clinic and hospital level - with the latter posing significantly more problems because they are fewer in number and generally situated in towns or cities. There was a general perception that the health care centres that provided ARVs were situated too far away and were thus inaccessible. People used a variety of means to travel to the clinic and ARV health facilities - these ranged from walking, taking taxis, hiring private cars, and in some extreme cases, using wheelbarrows.

The reported financial costs of travelling to a clinic ranged from R10 to R400 (in cases where a private car had been hired to transport a patient). In urban areas, financial costs appeared to be the greatest inhibiting factor in accessing treatment, while in rural areas, it was a combination of unaffordable travelling costs coupled with an unreliable or non-existent public transport system due to poor road infrastructure. In some instances, the preference for the use of traditional healers over health facility staff was due to the formers accessibility and location within the community. Mobile clinics were described as unreliable.

It is very difficult to transport a person to a clinic or hospital because there are no access roads. Clinics and hospitals are far from the community 
Interviewer: How far is the clinic if you are walking?

Respondent: It is too far and you can't make it if you are sick... We pay R5 for a single trip after you have walking about one hour distance. It is more than one hour if you are sick.... We also have problem of poverty in this community, as many people are not working.... Many people are sick and they don't have money to go to clinic or hospital.... There is no transport and there is no money.

Woman, Maphumulo

The transport costs involved in attending ART literacy programmes with a patient supporter was also cited as a deterrent to the uptake of ARVs. Being in receipt of a disability grant (payable when the CD4 cell count is 200 or less) appeared to render transport costs less onerous. Of concern was the tendency for people to resort to moneylenders to finance their travel and related costs to visit a health facility.

A person needs to take transport to get there. If one does not have bus fare, that would mean s/he would not get his/her treatment in time. The person has not started getting this grant and family members cannot help because they can't afford.

Community health worker, Chesterville

Patients don't work and therefore when we refer them to hospital it requires money and they default because they borrow money and therefore are afraid to say that they have a problem to neighbours, as they would have to disclose their status. Therefore they say its better to stay at home.

Clinic staff, Maphumulo

I might be positive but I have not tested, and would like to test but places where testing is done are too far.

Community member, Maphumulo

Sick people don't have money for transport when they have to collect treatment. If you go there you need transport money and you need to buy something to eat. If you haven't got your grant you will go to the moneylender.

Person living with HIV, Chesterville

A common theme emerging from all discussions was the need for treatment to be made available at local levels (e.g., clinics) and for NGOs and CBOs to be more involved in its delivery.

I would suggest they deliver the treatment at a particular household or at a community hall. So they would be an announcement that the treatment would be acquired at a community hall.

Person living with HIV, Maphumulo

Bring ARVs nearer to people- maybe at clinic level.

Church leader, Polokwane

I think if government can have a system whereby you can have access to treatment irrespective which province you are in. If the government can introduce system like barcode so that you can have access to treatment wherever you are. There are people living here who will go to their rural areas in December what will happen to those on ARVs?

Support NGO, Chesterville

\section{Stigmatised spaces}

Specially allocated VCT and HIV and AIDS treatment rooms can prevent uptake of treatment for fear of being identified as being HIV-positive. In some instances a lack of space was reported to 
compromise the confidentiality of VCT and acted as a deterrent against testing and receiving counselling. There also appeared to be reluctance to use services in which local community members were employed for fears that the confidentiality of their status would be compromised.

We have the problem of shortage of space therefore we have to conduct VCT in places where there is no privacy and clients are not happy about that situation.

Clinic staff, Maphumulo

There is no privacy as the VCT room is right in the middle of the clinic. It is very uncomfortable, as people in the clinic will can see all the people who go into the VCT room after which they will gossip and say, 'Did you see Mr. So and so coming from the VCT room?

Community leader, Sekhukhune

The other factor is that there is no confidentiality in hospitals. If a person attends the Clinic called Philani, which is located in King Edward Hospital, that means you are HIV-positive because not everybody goes there but only HIV-positive people. If you go to Ekuphileni Clinic in room 31, people will know that you are HIV-positive because there are many members of the community who come for different services. So people feel uncomfortable to go there.

Support group member, Chesterville

\section{Eligibility criteria}

Knowledge about eligibility criteria for ARVs was varied. People living with HIV and those on ARVs, as well as some health care workers, tended to have more information about eligibility criteria than ordinary community members. However, this information was not always accurate or complete. Most people were aware of the CD4 cell count eligibility determinant, but only a couple mentioned the World Health Organization's staging criteria. There was the perception that the CD4 criteria was too restrictive and that people often received ARVs too late. People who had CD4 cell counts of over 200 reported difficulties making regular trips to re-evaluate their CD4 counts.

Here in South Africa they use this less than 200 CD4 count policy. This is one of the problems because you may find that the person is very weak. This CD4 count method it gives us a problem as we are working with people who are HIV-positive because this is not about quantity but about the quality. There are people that have 26 CD4 count but doing hard work but the person who has 350 CD 4 counts is very weak and can't even walk. That is where the problem lies.

Support group member, Chesterville

The strategy that they use is not good because they keep people waiting to drop their CD4 count to less than 200 CD4 count. The people fail to improve after their CD4 counts have dropped. It is like they waiting for people to die.

NGO member, Polokwane

$A R V$ s have side effects so if a person starts ARVs while very weak it doesn't help but make the person worse. That is why people think that ARVs are killing people.

NGO staff member, Chesterville

I was tested at three months intervals since 2004 and when my CD4 count dropped to below 200 I was given antiretrovirals in 2005.

Person living with HIV on ARVs, Sekhukhune 


\section{Facility level constraints}

\section{Human resources}

All sites indicated that human resources shortages were experienced at health facility level. These shortages refer to nurses, doctors, community health workers, counsellors and home-based caregivers. Shortages were generally expressed by people working within the health system and not by users of the system.

We see more than 100 people a day, sister consults, I dress and inject people and this makes it a long process and therefore HIV-positive people have to wait too long. Sometimes the car that collects blood samples comes and we are not through with what we are doing and it leaves without the samples this ultimately delays the process of the return of results...Today it's the day of the ante natal clinic. We have to take time to consult with one mother-to-be because we have to counsel the mother about VCT and other issues related to her health. Meanwhile the other patients are waiting and they feel that we are taking to long.

Staff nurse, Maphumulo

My workload is very heavy as the clinic is always full. For instance when I am on leave nobody works in my place.

Clinic sister, Sekhukhune

For now, the problem is that the treatment is there but there is a shortage of staff. Only a few people can roll it out.

Clinic-based nurse, Chesterville

Shortage of staff is a problem in our clinic. We also have shortage of space.

Clinic sister, Polokwane

\section{Treatment by staff}

Respondents in KwaZulu Natal indicated that they were not always treated well by clinic and hospital staff and some suggested that they were discriminated against as a result of their HIV status. Other respondents felt that they were not routinely given information about their health and reported being sent to various different places for a variety of tests. Comments about rude treatment from staff were noticeably absent in Limpopo Province perhaps because there are more organised functional clinic committees in Limpopo, which might have contributed to better staff attitudes and client relations.

The doctors have taken blood from me that can fill a large basin. I asked them to tell me the level of my CD4 count. I went to King Edward, when I had to get those results; they told me to start the test all over again. I went to Wentworth Hospital, they punched my ID number in the computer when I asked for my result, and they didn't give it to me. When I went with my child they still didn't give me the results. They said I did not come when I was supposed to do so. I had to start all over again. I explained to the doctor that he has to be patient with me because I could not come when I did not have bus fare since I am unemployed. When that I happens, I just stay at home and continue to get sick and he would not know how hurt I was because of that kind of treatment/behaviour.

Person living with HIV and support group member, Chesterville

At clinic they treat us very bad like if we ask something they say we didn't send you to get this disease. We don't get good treatment at the clinic.

Person living with HIV, Chesterville 
We also have problem about our clinic staff they don't give good care if we are at the clinic. Some of them are good and some are not good. There is nurse that many people don't want to be treated by her. People prefer to die than treated by that nurse.

Woman, Chesterville

There was an imbizo (community meeting)... which was organized by Department of Health. When people got there they don't get the chance to raise their concerns. I was there and people were very angry because they wanted to raise their concerns but the Department of Health just made some speeches. People were very angry about the clinic called...but the Department of Health was praising the clinic with their performance.

Community health worker, Maphumulo

\section{Infrastructure}

All sites reported old, dilapidated or insufficient facility infrastructure. Infrastructural constraints included shortage of space and equipment. These issues tended to feature more prominently, although not exclusively, among health facility staff rather than users of the clinic.

We also have shortage of space. Instruments that are required to take vital signs are not sufficient. The lactic acidosis machine is presently not available... and this is very inconvenient.

ARV co-coordinator-nursing sister, Polokwane

The hospital is overloaded with ill people and there is no space to sit. There are people lying on veranda and outside on the lawn.

Woman, Maphumulo

Continuity of ARV supply was also raised as a problem in one site and could become an issue in other sites as the rollout process becomes more intensive.

There was woman that was the member of our support group. She died last week. She was attending training for ARVs. After she had finished the training she was given a date to collect the treatment. When she arrived during the due date at hospital they told her that ARVs are finished. How can the ARVs be finished while we have to take it on a particular time? They are contributing to our deaths.

Person living with HIV, Maphumulo

\section{Cluster Three: Experiences of People Living with HIV and AIDS}

This section sets to explore specific experiences of people living with HIV and service providers in order to document real experiences of service use and the barriers and challenges of accessing treatment.

\section{Family and community attitudes}

The research revealed a range of responses to HIV-positive people in the four study sites. The responses below focus on responses based on the actual experience of people living with HIV and AIDS, rather than their perceptions, to paint a more accurate picture of what is occurring in the four communities. 


\section{Service providers' perceptions and experiences}

Many service providers and community stakeholders indicated that people living with HIV would be rejected if they disclosed.

They are scared to disclose their HIV status, as they fear rejection by their family and by the community and their friends.

Clinic sister, Maphumulo

Nobody discloses and no one comes out to say they are HIV-positive...there is one young girl who is very worried because everyone knows she is HIV-positive. She is trying hard to hide but it is widespread knowledge.

Clinic committee member, Maphumulo

The main problem was that family members did not want to accept their children who are HIVpositive.

Chairperson of hospice, Chesterville

Service providers also cited actual examples of situations where families neglected people living with HIV.

They used that bathroom as his bedroom. They put a mattress there and pull the door because he has bad smell. They didn't bath him. They don't do anything to him. The caregiver was visiting him even during the weekends...hospitals also don't want people with HIV/AIDS as much as their families don't want them.

NGO worker, Chesterville

Sometimes they hide the person and isolate them until they die due to lack of care. We as homebased caregivers have to work hard and make sure that this does not happen.

Home-based caregiver, Sekhukhune

In some cases people were stigmatised for caring for people living with HIV.

One family member was sick and the wife of his brother helped him. Her partner abandoned her because she was helping the person who is HIV-positive, which means she is also affected.

Community leader, Maphumulo

In some cases caregivers spoke of the being turned away by families and of receiving a better response from families when they didn't wear their uniforms and could not be easily identified as caregivers.

Some families don't even want us as caregivers to visit patients in their households. They actually chase us away. They would rather hide the patient and deny the status of the patient until the patient dies. Our success stories are therefore equal to our failures.

HIV-positive caregivers, Polokwane

They (families) usually accept $H B C$ when the patient is unable to walk because then they need assistance with care.

HIV-positive caregiver, Polokwane

However, there was also general consensus that families played the major role in assisting people living with HIV and were generally more accepting of them than the community at large. 
The community is normally afraid of such a person... Sometimes it's only the immediate family that will support the HIV-positive person.

Male, Polokwane

Family members support their sick people, they provide all (the) support... People from outside family are scared to help if a person is sick and suspected that she or he has AIDS. They fear that they might contract HIV...if they help that person.

Reverend, Maphumulo.

Only their families know and support them. Sometimes they don't even assist but reject family members who are HIV-positive...HIV is a hidden thing in the community.

Person living with HIV not on ARVs, Maphumulo

\section{Disclosure}

People living with HIV also reported that the fear of suffering negative consequences prevented people from disclosing.

They are scared to tell others about their status because other people will tell others about their status, particularly those who are not sick, they like to talk bad about HIV-positive people

Person living with HIV, Maphumulo

In the community people keep the information to themselves, sometimes they do not even want to tell their families because they believe they might be told to cook and eat alone.

Person living with HIV, Maphumulo

Individuals living with HIV reported a range of experiences in terms of disclosing to family members and spouses. In order to access treatment, many had to disclose to a supporter, usually a family member. Most often this supporter was a mother or a female family member. There were also people who had disclosed to their sexual partners. In some cases this had been a positive experience:

I told my mother the same day as my result. She accepted me but I think it was easy for her because she is working with sick people (she is a community health worker). I know that we have different parents. Others would not act as my mother did to me.

Person living with HIV, Maphumulo

It's actually the support I that I received from my family more than anything...After testing positive I told him (her partner). He also went for a test and we both support each other...His support really helped me.

Person living with HIV, Polokwane

After I had tested positive I told him (her partner) and he went for the test and he tested HIVpositive. We then agreed that we will love each other as we know that we are both HIVpositive. We can't run away from each other.

Person living with HIV, Maphumulo

However there were also instances where disclosure had resulted in abandonment. Service providers and community stakeholders also recounted similar stories.

There is a woman who tested positive and she told her partner. Her partner left the house since that day and never came back. He left her with children. He didn't even tell her where he was going.

Social worker, Maphumulo 
There is my friend that was sick and was chased away by her partner because she was HIVpositive. I helped her looking for her relatives. She was staying here at hospice.... Her body was in mortuary for two weeks because we didn't find her relatives.

Leader, Chesterville

Some people living with HIV felt that they needed to distance themselves from friends in case their status was discovered.

One is sometimes scared that people will laugh at him or her if she or he is close to you, so you would think its better to allow some distance between you.

Person living with HIV, Chesterville

Interviews and focus group discussions with youth in Limpopo and KwaZulu Natal seemed to indicate that urban youth were more sensitive in terms of supporting people living with HIV and were more open to disclosure. For example, during a FGD with youth in Chesterville respondents indicated that young people felt more confident about telling people they were HIV-positive. One member of the group openly declared his status during the FGD.

I also say I can disclose my status because I have a friend who is like that, who came out and told us. She does not hide anything.

Woman, Chesterville

I have a neighbour who is HIV-positive and I try to give her attention and be normal.

Woman, Polokwane

Well, I agree that we should give that person support and be normal towards that person.

Male, Polokwane

However youth agreed that this is not the case for all people in their communities. The youth felt that they have different attitudes toward people living with HIV than other people in their community as a result of the life skills education they got at school, which included education on stigma and discrimination.

Other people living with HIV found that they were able to disclose to a wider audience than their families or treatment supporters. In some cases people did not believe the individual was HIV-positive even after disclosure.

I tell people that I am HIV-positive and answer all their questions about HIV. People in my community welcome me and I don't feel snubbed by anybody. I answer their questions as much as possible and I think its part of education to my community on issues related to HIV.

Person living with HIV on treatment, Sekhukhune

You can tell your friends but they don't believe you. I have told them that I'm HIV-positive but they said I'm lying... maybe they don't see any symptoms of HIV and they say I'm fat than thin.

Person living with HIV, Maphumulo

\section{Families willing to care for people living with HIV}

In some cases family members spoke about knowing their children were ill but not being able to do anything about it. 
(He) was 28. He was my son and died of TB.... He did not tell us that he was HIV-positive. However, we were aware he was HIV-positive. We tried to take him to faith healers and the hospital, but later he died.

Clinic committee member, Maphumulo

We heard that she (the child's mother) was told she is HIV-positive, but she ignored it. But we think she went for HIV test. We also know that our son had AIDS when he died. There is another partner who has his children and we think she is also HIV-positive because she had his children.... We only know that he (the son) was HIV-positive after it was discovered from his child. We haven't asked her if she has done blood test because it is a shameful thing to ask my daughter-in-law about this.

Grandfather, Maphumulo

However, other respondents related how they have dealt with having HIV-positive family members. A reverend that had spoken openly about having an HIV-positive son at church said:

I want to show the community that there is nothing wrong with disclosing about the HIV status of your family member. I also want the community to be aware that I can advise them about what to do if one of their children is HIV-positive.

Reverend, Polokwane

Respondents felt that family members, who often are the primary caregivers, need a better understanding of the disease if communities are going to deal with HIV and AIDS more effectively.

Teaching families is important because it makes it easier for people to disclose to their families. If families can understand that HIV-positive people are not abnormally sick, they are just like people who have diabetes or cancer.

Community health worker, Chesterville

Addressing misconceptions about the transmission of the disease at family level would also help to address some of the stigmatisation being reported.

I wish people could be taught that this can only be transferred through blood and not being physically close to another person.

Person living with HIV, Chesterville There also seemed to be the impression that through experiencing HIV and AIDS at household level, families have a role to play in helping communities deal more sensitively with people living with HIV.

I think each household can do something after they have experiencing this problem of HIV/AIDS because it is a different story once you have a HIV-positive person in the family. I think there are few people who don't have this problem.

Person living with HIV, Chesterville

\section{Disability grants}

Disability grants were a major concern for people living with HIV. Concerns included the eligibility criteria and the possible impact of social grants on uptake of and adherence to treatment. 


\section{Eligibility for grants}

Many people living with HIV spoke of the difficulties of securing grants for themselves and their dependents. With provinces using CD4 counts as eligibility criteria, the process of getting a grant was long and uncertain.

When I was there the sister that helps us told me that my CD4 count are higher and I'm not qualify for the grant as I wanted to fill the form for the grant that is received by person living with HIV. I asked her why we are not qualified as we are HIV-positive and how will we maintain our life because they say we must eat healthy food, but we don't have the money.

Person living with HIV, Maphumulo

When we apply for grants sometimes we are not successful. Our parents only receive pension, which is not enough to support us and our children. Now we find ourselves being burdens to our parents.... the government doctor does not want us to receive this grant. I don't know why he wants us to work when we are like this. He fails you in the test you go through in order to qualify for the grant.

Person living with HIV, Chesterville

I later went back to check on my CD4 count and found that it was 290 and that I did not qualify for a grant.

Person living with HIV, Polokwane

The process of getting a grant was also time-consuming.

I tested my CD4 count in March and got on ARV treatment in August and that is how long it also took me to get a grant.

Person living with HIV, Maphumulo

The problem is the process of doing birth certificates and the process of doing the grant...I can say there are twenty people on waiting list for grant and twenty for ID books and certificates the grant helps for people who have no financial support at all. There are people who left employment because of illness. Some of these people are the breadwinner and you may find that no-one is employed in the family.

Social worker, Maphumulo

People living with HIV also struggled to get additional social support for their children. Often these individuals were women with children, some of who were also ill.

I am on a grant as I am a widow as my husband died... I have a child... unfortunately there was confusion about her date of birth...therefore they refused to give me a birth certificate and until now I am not receiving a grant for my child.

Person living with HIV, Maphumulo

Yes, I do receive the grant, but it is not enough if you are not employed because all these children are depending on me.

Person living with HIV, Chesterville

\section{Impact of grants on treatment uptake, adherence and follow up}

The provision of grants only to people living with HIV with CD4 counts below 200 may have negative consequences in terms of treatment. People may not want to access treatment and lose their grants, or may not adhere to treatment. Others only access CD4 counts as a means of getting a grant and do not use services. There was a perception that there is nothing available for people living with 
HIV with CD4 counts above 200 as they do not qualify for grants or treatment and yet face many of the same problems as those with CD4 counts below 200 .

One community health worker reported that there is one man who said he is on ARV treatment. The man said his interest is the grant. Family members are not sure if he takes the treatment. Social worker, Maphumulo

Others come with the aim of getting the grant. Most of the people come here with letters from the doctor that says that the person is qualified to get a grant. If they see that they won't get the grant, they don't come back.

ARV clinic staff, Chesterville

\section{Experiences of people on treatment}

\section{Adherence and side effects}

The introduction of treatment in the public sector has raised concerns about adherence. Service providers at ARV centres spoke about how they determine if people are ready to start ARVs.

We look at things that can motivate people to use treatment. The important thing is that the patient must know how ARVs work and what will happen if they take treatment accordingly. They must also know what will happen if they don't take treatment accordingly. I mean the good and the bad side of treatment.

Staff member at ARV facility, Polokwane

Many of the people on treatment interviewed spoke of experiencing mild side effects initially. All of the people on treatment seemed to have a good grasp of how to take ARVs and were finding the side effects manageable. Common side effects mentioned included dizziness, rashes, diarrhoea, disturbed sleep, and numbness of limbs.

At the beginning I was dizzy and I had a rash and diarrhea. When sleeping I felt as if the world was turning round and round now that has stopped. However, now, my skin is rough and my feet feel numb especially at night.

Woman on ARVs, Sekhukhune

Because when I took the night dose I used to have hallucinations. I used to see water or strange looking animals. This is however at the initial stage and now the side effects have ended.

Person living with HIV on treatment, Polokwane

I have frequent rash in the body and vagina. My feet have a burning and itchy feeling and this is more common when it is hot than when it is cold.

Woman on ARVs, Maphumulo

Other challenges to adherence reported by service providers included traditional beliefs, lack of disclosure, and the distance to hospitals.

Some come from very far and they default because they come from very far and the staff in the clinic is very small to follow up on people from the community... people are also afraid to travel long distances as there are criminals that attack them in lonely roads. There are about 12 villages and some are very far.

Service provider, Maphumulo 
The main challenge is the fact that people default due to belief in traditional medicine and the fact that they believe that they have been bewitched...Some family members fetch their relatives when they are already admitted into hospital for treatment saying that they want to take them to traditional healers and then bring them back to us when their situation has deteriorated.

Service provider, Sekhukhune

Some people don't tell their families that they have tested positive and it takes a while to convince them that they have to disclose to their families...Sometimes a HIV-positive person chooses a minor to be their support and refuses to choose someone who works in the family and then funding for transport becomes a problem, as the working family member would refuse to provide financial support thus causing the patient to default.

Service provider, Sekhukhune

There was also concern among service providers that there was insufficient monitoring and follow up services for those on treatment. Service providers in rural Limpopo lacked transport to follow up on their patients.

Even though we don't have many defaulters, but it seems the number will increase.... I think a better solution would be to use the method used for DOTS. The TB program does trace their patients at their home. If we can use this method to monitor the people who are on the ARV program it could be much better.

ARV clinic staff, Polokwane

On the other hand, many people on treatment spoke of being able to manage their own health and of the various mechanisms they use to remind themselves to take their medication. In addition, ARV facilities also make patients return regularly to facilities to collect medication and keep track of the doses issued.

No one follows up, however to me this is not a problem, as I believe that my health is my responsibility. I am not worried if they don't check on me as I can still look after myself. They check and count the pills before you get them.

Person living with HIV, Maphumulo.

They give an allowance of two days for the next visit before the pills get finished...to make sure that I don't finish the pills before the next visit. Initially when I started she [her sister] would call me every morning at 8am to remind me as she works in town. At half past eight at night she called me and in the evening when my father was back from work he also reminded me. At Hope Centre they actually encourage us to buy cell phones in order to set alarms so that we don't forget to take our medication.

Person living with HIV, Polokwane

\section{Nutrition}

Limited nutritional support is being provided to people living with HIV, with the majority only receiving nutritional advice. Some received ad hoc or inconsistent nutritional support in the form of supplements or food parcels, in some cases limited to the supply of porridge. People living with HIV in all the sites felt that they were not able to follow the advice on nutrition provided at clinics and hospitals. Lack of food seemed to play a role in poor adherence and poor uptake of treatment services.

I eat whatever I have at home. I try to have a variety of food and vitamins as we were taught on ARV training. However, I run short of money sometimes and am assisted by the porridge we get from the clinic. This however is not available sometimes.

Person living with HIV, Maphumulo 
One of my clients fails to take treatment because she didn't have food. I went to the hospital to report the case. You can take treatment before meals, but you must eat something later...that person has nothing at all. We then organized food parcels for her and she continued with her treatment.

Patient advocate, Maphumulo

NGOs were also providing nutritional support, mainly by encouraging people to grow vegetable gardens or in some cases where resources permitted, by providing meals or food parcels. However in some cases, NGO staff reported that people were unable or unwilling to improve their own diets, because of lack of resources and weakness.

Many people living with HIV interviewed spoke of using "immune boosters." Traditional healers interviewed also spoke of providing people living with HIV medications to boost their immune systems. Knowledge of immune boosters was widespread in these communities.

I do it myself because they told us to use African potato.... I got this information from Tongaat clinic where I attend the class...we mix African potato, unwele, ilabatheka and spirulina tablets.

Person living with HIV, Maphumulo

I take Bactrim and spirulina that I use to boost my immune system. I also drink $100 \%$ juice. I buy the juice if I have the money... we also buy pills from the chemist to boost immune system. These pills are very expensive...the treatment I was using costs R1,500, this is the product from Swiss Garde, if you are earning well. It was a set of pills, powder, bathing set and aloe vera. I bought it once. Now I only buy one set for R300 in order to have something to drink for immune system. I also buy tea for thrush, which costs R75. This tea helps for appetite as well. You can use the tea bag four times.

Person living with HIV, Chesterville

There is one herb called African potato, it helps and I'm the witness because I have seen people who have used it. They mix it with other herbs... we advise people to use these herbs if they haven't started treatment or if they haven't decided to start ARVs.

Member of youth organization, Maphumulo

There are people taking traditional herbs and immune boosters from Golden Products. Others they know they will not cope with adherence with treatment and for that reason they prefer to take immune boosters.

Social Worker, Maphumulo

Sometimes they say when you drink five bottles of traditional medicine, the virus gets finished and you become HIV-negative...it's the hearsay, it's like the ARVs and we hear they lessen the virus in your body.

Youth, Chesterville

Immune boosters are available from various sources in the community including from tradition healers and from community members selling products at various locations in the community.

The organization is formed by...traditional healers and faith healers who are selling herbs to people living with HIV/AIDS...our objective is to help PLHA because most of them don't have money. We provide (them) with juice, which is mixed with fruits and vegetables and traditional herbs like pineapple, apples, sweet potatoes, sweet potato leaves, wild spinach and African potato. This is the immune boost. We also recommend our patients to use aloe. We helped one person who had less than 200 CD4 count and her CD4 count increased to 1004. After she went 
to the hospital and they tested her, they found that her CD4 count has increased and asked her what helped her. She told them about the juice that we are making...we have our phone number on the $750 \mathrm{ml}$ bottle...we charge them R10 per bottle. Our juice is available in different places like Stanger town, Maphumulo town, in the local tuck shop in the community. It is also available in Maphumulo VCT clinic.

Traditional healer, Maphumulo

I sell the immune booster tablets. I sell it to them at the price I get them...R150. Sometimes I give them and they pay in small amounts until they finish. I am just helping them.

Church leader, Chesterville

In some cases, people were reluctant to be seen purchasing immune boosters since these were linked to people who were HIV-positive.

The thing is most of the people sends others as they are scared of being known and exposed as HIV-positive.

Church leader, Chesterville

\section{Paediatric treatment}

Many of the people living with HIV interviewed had children. Some respondents recounted how their infants and young children had died before treatment was widely available.

My grandchild died because of AIDS. Firstly this child got tired and we took him to hospital. He later died. We discovered he was HIV-positive.

Clinic committee member, Maphumulo

I was also shocked after getting my results about my status. The doctor checks the baby first and I don't believe the result from King Edward and I took the child to Poly Clinic at KwaMashu and results were HIV-positive.

Person living with HIV, Chesterville

The above respondent's baby later died. The baby was on prophylaxis treatment but not on ARVs. At the time (in 2000), treatment was available at McCord's Hospital but only for subsidized paying patients.

Some of the women interviewed had taken Nevirapine. In some cases respondents reported that their children were HIV-negative. One woman in Chesterville spoke of how she had lost her daughter and grandchild to AIDS. Her daughter had another child before she died and that time she was able to take Nevirapine. Her remaining grandchild was HIV-negative and was 4-years-old. However, the lack of PCR testing means that parents often waited a long time to find out their children's status, causing considerable anxiety.

She is healthy and fit. She is not HIV-positive. She has been tested three times but I don't know because they say you can do many tests...maybe on the fourth test you could find that she is HIV-positive.

Person living with HIV, Chesterville

In some areas there were children on treatment. For example, a patient advocate in Maphumulo said she knew of ten children on ARVs in her area. In many cases the primary caregivers of HIV-positive children were their grandparents. Elderly caregivers often struggled to provide for a young sick child. Often these caregivers found out about the status of the children left in their care only after the parents of the children had died. 
He stays with his granny but the granny has problems because the father of the child is also sick and she doesn't have money to support these people. The granny is not that old to qualify for old age pension. She is surviving....as (a) domestic worker.

NGO worker, Chesterville

He was diagnosed HIV-positive long time (ago) because of many illnesses that is why he delays to take treatment.... He was on treatment for a long time for TB and pneumonia. He just started ARV treatment on Thursday.

Grandfather of an 8-year-old, Maphumulo

We were not aware the child was HIV-positive...there was no HIV treatment by that time. The child is 8-years-old now; he started the treatment last year (2004).... After that it is clear that the child was left with me. I continue to go to King Edward Hospital and the doctors were helpful to me and they appreciate the health of the child since I took over from her mother.

Grandmother, Chesterville

\section{Support groups}

The research found a variety of opinions on the benefits, challenges and sustainability of support groups. Benefits included that they provided increased access to information, the opportunity to share common experiences, and a forum for discussing problems and giving each other advice. Support groups were also linked with other resources like income generation activities and access to nutritional support. In some instances people living with HIV reported receiving support and preparation for disclosure. Some also spoke of support groups as simply providing them with a safe space where they could engage in conversation and enjoy themselves in addition to a venue for talking about the disease. However, people living with HIV did not always have the resources to attend support groups or feel well enough to travel to these meetings, usually located at health facilities.

The good thing is that people are gradually responding positively to support groups and these assist to alleviate stress and fear among people living with HIV.

Lay counsellor, Polokwane

We are sharing information and problems and how to deal with those problems. There are many people who have problems with disclosure at their homes and to their partners...the problem at the moment is that we have few members in the group. We meet once a month because they come from different places and they don't have money.

Social worker, Maphumulo

The support group therefore helps in that we are able to share ideas and these assist us to help each other and our lives improve. In our group we have people who are ready to stand in public and talk about their HIV status because we give people confidence.

HIV-positive caregiver, Polokwane

I get a lot of support from the HIV support group we have in our community...in the support group we are able to share our problems and we help each other. The support group is very useful as we are all HIV-positive and understand each other's problems.

Person living with HIV, Maphumulo 
When we talk we don't always mention that we are sick. We just talk as friends and advise each other...in my support group - we talk, we laugh and it's hard for someone to recognize that we are sick if we are together.

Person living with HIV, Maphumulo

Respondents also mentioned challenges to forming and sustaining support groups, including the impact of stigma and the difficulty of retaining support group members.

Community health workers have tried to organize support groups even though they are not very effective. People still have fear of stigma to participate in support groups. It would be better if there were many different groups, which involved different diseases to avoid stigma.

ARV facility staff, Maphumulo

I approached one youth and asked her to teach on HIV/AIDS and to form a support group. She said she was afraid that the community would reject her

Clinic staff, Maphumulo

We are trying to form a support group but the problem is HIV-positive people are not consistent. Every month when we meet a new group comes and those who attended the previous month drop out. Every time we meet we start afresh and progress therefore is very slow.

Person living with HIV, Polokwane

We tried to form one but it did not succeed because of fear of being identified and stigmatised. Even TB patients refuse to form a support group

Clinic staff, Sekhukhune

\section{Cluster Four: Role and Capacity of Community Organisations}

\section{Community involvement in HIV and AIDS}

There were low levels of broad community involvement in HIV and AIDS issues in all four sites, although pockets of activism existed in each. This activism took the form of support groups, homebased caregivers, fostering, clinic committees, and community health workers. These roles tended to be filled mainly by women on a volunteer basis without remuneration. In all sites, there were signs that HIV and AIDS is finding its way onto the agenda of other mainstream activities of the communities. In Maphumulo for example, a community health worker has been given a regular slot at a church to talk about HIV and AIDS. In Sekhukhune traditional healers have received training on HIV and AIDS and the use of sterile equipment. In Chesterville a community-based organization delivers talks on HIV and AIDS at funerals, and in Polokwane a local church convenes weekly discussion forums for the youth on issues related to HIV and health.

\section{Current initiatives}

\section{Home-based caregivers}

Home-based caregivers function as an important source of support for people living with HIV. The study found that most were women, with little consistency across sites regarding whether they worked on a paid or volunteer basis. Depending on the needs of the area and their training, they provided a wide range of functions including home visits, palliative care, education, treatment advocacy and support, referrals for grants and health services, patient follow up, and counseling. 
We bath people and provide nappies for those who have diarrhea and who are unable to help themselves.... We also provide powder that prevent skin rash.

Home-based caregiver, Maphumulo

We teach families how to take care of their HIV-positive family members and we also assist family members to accept and understand the HIV-positive family members. We also help the $H I V$-positive person to accept their status.

Home-based caregiver, Sekhukhune

We look after terminally ill patients and we don't only look after HIV-positive people we also look after old people who are unable to look after themselves and we also help orphaned children and disabled people.

Home-based caregiver, Sekhukhune

In some cases, home-based caregivers are themselves people living with HIV.

All caregivers in the project are volunteers and we are PLHA. As a result we feel that we understand problems of HIV better as we experience these problems, we feel that it is PLWA who can effectively plan, understand and look after other people who are living with AIDS.

Home-based caregiver, Polokwane

All home-based caregivers reported significant challenges in their work, most of which related to working in very resource poor settings. They reported inadequate supplies of materials, not having access to nutritional support for their clients, lack of transport, and difficulty managing the expectations of their clients. The lack of a stipend also featured as a problem.

We visit three households per day. We walk long distances as they are far apart from each other...we are cover three areas. We are walking maybe three to four kilometers a day.

Home-based caregiver, Maphumulo

We go round to individuals to provide assistance and to teach families but we don't have enough resources to assist and we need to be supported more in the area of teaching about HIV and AIDS. The problem of disclosure is very serious in this area of ours and we need to receive support on the manner of teaching people to feel comfortable to tell their families about their status, as this is a serious problem in our area.

Home-based caregiver, Sekhukhune

Bringing them food is one of the things that shows that we care; however the problem that we are faced with is that more often the government does not provide food rations to the community and therefore we are unable to cook for them; we sometimes have to take our own food to cook for these patients as we realize that they are extremely poor and they become grateful when we provide food for them.

Home-based caregiver, Polokwane

We need a small stipend that could assist us to travel to some of the places where assistance is required. We are poor people who don't even have enough food to eat therefore it would be helpful to receive a little money that will assist us.

Home-based caregiver, Sekhukhune

\section{Community health workers}

Where they exist, community health workers are the front line workers dealing with prevailing health issues and have an important role to play in health promotion. Their role becomes especially critical in the context of the Operational Plan, which envisaged that CHWs will assist in promoting adherence, 
providing on site care and undertaking outreach programmes. At the time of the study, they were nominated by the community and were seen as a link between government facilities, NGOs, and the community. Theoretically, they were meant to perform different duties to home-based caregivers, with special emphasis on health promotion and educating households in caring for people living with HIV. However, this did not always happen in practice.

In our door-to-door visits, we are able to see if there are people who need to be visited constantly. Some people need to be supported with food and we have to prepare food for them...the way we work is, normally after having a workshop perhaps about cholera, and then we would go to different houses educating them about it. Other than that, we always visit people who are sick, who need to be taken care of.

Community health worker, Chesterville

We were introduced to the clinic staff members. What happens is that sometimes the nurses would ask the patient if they would like us, as community health workers to get treatment for them from the clinic to their homes, just like it happens with the TB treatment.

Community health worker, Chesterville

We have community health workers even though they are not providing treatment but they are observing patients and their households.

Patient advocate, Maphumulo

There are CHWs that are working in our communities. They visit our houses but they don't talk about HIVIAIDS. They check if children have gone to immunization and they also check if we are using clean toilets.

ARV class member, Maphumulo

In Maphumulo, CHWs were far more visible to community members than NGOs and were perceived as the only active community members.

The only people helping in this community to deal with this situation are CHWs even though they are not enough to deal with this situation. We still need more CHWs because this community is very huge.

Community leader, Maphumulo

I don't have information about NGO's. The only people that I know that they are helping sick people in this community are CHWs.

Reverend, Maphumulo

Challenges facing the CHW program included their relationship with health facility staff and role confusion with $\mathrm{HBC}$ volunteers and patient supporters. Some indicated that they did not receive any feedback on information they provided on their work. Lack of training, particularly on HIV and AIDS and ARVs was identified as a shortcoming.

We reported that caregivers and CHWs are having problems in terms of their service. CHWs are not even use gloves because they educate family members how to treat their sick people. They don't even touch sick people while us as care givers we remove everything and bath a patient and rub a patient. We have aqueaous cream. We have everything and even clean a patient's mouth like thrush. We leave the patient clean because family members scare to touch them when they are like this.

Home-based caregiver, Chesterville 
Yes, we work very well with them [social workers]. We conducted research on food parcels. We do monthly reports to the Department of Health. They receive those reports and turn away. We do not even know where they go to and what do they think of our reports. They don't do followups on the information and contact details provided in the report. Sometimes we ask ourselves, why do we have to do the research if it is not going to help anybody?

Community health worker, Chesterville

I'm a patient's advocate. I help sick people in the communities. I help people who are HIVpositive who have disclosed their status and those who are sick irrespective of what their illnesses are.

Patient supporter, Chesterville

As community health workers, we have not been given training on ARVs, whereas people ask us, as they know that we are community health workers. Then you find that we do not know as well.

Community health worker, Chesterville

\section{Clinic committees}

Three sites had clinic committees consisting of community members. The levels of their functioning and their perceptions of their scope and role varied.

In Chesterville the now defunct clinic committee consisted of 15 to 20 community stakeholders. After its formation, the committee had met a few times but was not been able to convene a meeting since. Reasons for the poor functioning of the clinic committee include poor communication, lack of support from the $\mathrm{DOH}$, high clinic staff turnover, and problems in setting meeting times.

The clinic committee in Maphumulo, which initially consisted of seven people, had whittled down to four at the time of the research. Reasons for the attrition in members included death and relocation of two members to an urban centre. The clinic committee identified HIV and AIDS as a significant problem in their community and was playing a role in educating youth about the issue. Despite its small numbers, the committee was functional and reported a positive response from the community when invited to attend meetings.

Knowledge on ARVS is still limited. Our role as the clinic committee is to advise young people to go to the clinic. We go to places where young people usually gather including churches and we advise them.... and to tell them if someone confides in them they should take that person to the clinic for VCT. We use the church as an entry point. Young people in church even go to jail to teach about HIV and AIDS.

Clinic committee member, Maphumulo

The role of the clinic committee in the communities were described as follows:

We help the support group and VCT counsellors. The support group presently has a communal garden outside the clinic where we demonstrate nutrition. We also work as spiritual supporters as we have prayer meetings on Thursdays at our churches where we advise on HIV. We advise young people to behave and to be disciplined in order to avoid premarital sex.

Clinic committee member, Maphumulo

The clinic committee is a link between the community and the clinic and we as clinic committee members look at the manner in which nurses attend to the community and we assist by looking at people who desperately require assistance and oversee the general cleanliness in the clinic and ensure that the cleaning are available and that they actually perform their duties in time.

Clinic committee member, Polokwane 
The clinic committee in Polokwane adopted a broad approach in fulfilling its mandate and provided assistance on a variety of issues. Eight members of the committee were trained in TB and HIV and AIDS issues and actively assisted the clinic by following up on patients and providing support and care to patients.

If we find that the place is dirty we clean the place and if there is no food we follow up with social welfare through the clinic. We have a clinic garden where we take vegetables if someone is hungry and we cook for them. We provide community health on behalf of the clinic and this is part of the terms of reference of the clinic committee. Sometimes we provide assistance in the clinic by having health desks and here we mobilize the community by encouraging them to use the clinic. For instance we encourage mothers to keep coming for growth monitoring by showing the importance of bringing children for growth monitoring.

Clinic committee member, Polokwane

\section{Challenges to community involvement}

Despite some initiatives, community involvement was beleaguered by a host of challenges including lack of leadership, lack of credibility and the fact that people still needed to be convinced of the dividends of community involvement. Given the stigma associated with HIV, community involvement might result in secondary stigmatization. There were few positive examples of community involvement in HIV and AIDS for people to draw on.

It's difficult for me to say what role they [community] should play because I don't want them to know, as once they know they will start gossiping and that will hurt me.

Person living with HIV on ARVs, Maphumulo

The community is not active enough in HIV activities it would be good to see more people involved the problem is that people are not free to talk about the problem of HIV.

Community leader, Maphumulo

I don't think there is much NGOs can do. This virus is in my blood and there is nothing NGOs will do to remove the virus from my blood.

Person living with HIV, Polokwane

We have many leaders in Chesterville but their focus is on housing only and they don't care about sick people. If they have an interest in helping sick people I think they should come together as leaders and do something. They don't even talk about HIV/AIDS in the community meetings.

Chairperson of hospice, Chesterville

\section{Relationships with and between CBOs and NGOs}

With the exception of a few CBOs that are predominantly involved in providing home-based care, community members did not report any close links with NGOs working in the area. Respondents in all sites were skeptical about NGOs, citing that they did not always act in the best interests of the community, that they were fragmented, and that they did not work together. However, in all sites NGOs were identified as having a critical role to play in supporting treatment initiatives and in educating communities on HIV and AIDS.

NGOs must stop misusing funds and work and deliver to the people. If NGOs can work together maybe we won't have problems... There is lot of white people in NGOs and there are very few black people. White people come in our communities with projects. We don't know where they get money from. They come with very little help and take photos. We need NGOs that are from 
the community because they will have their sympathy with these people rather than a person from outside whose interest is on money. If NGOs can sit together and make one proposal I think that will have good results.

Chairperson of $\mathrm{CBO}$, Chesterville

The other problem is that the organizations from the communities are more focused on gaining money. It is good for the organization to have money; but at the end of the day must plough back the money to the community if they get through the community. Other people they don't care about the community but they are interested on money.

Chairperson of support group, Chesterville

NGOs need to sort out their differences about areas where they operate.

ARV coordinator, Polokwane

We need to unite with them; work together because their work is good. Our work is good as well but if we can work together, that can be perfect. Chesterville is a small place; we do not to have a lot different groups because we discriminate against each other at the end, to the community that we have to serve, so people do not say that we get paid for nothing.

Community health worker, Chesterville

\section{Suggested roles}

The following strategies and roles for optimal community, government and NGO involvement emerged from the FGDs and interviews in the research sites.

\section{Community members}

Community education on HIV, AIDS, and ARVs was cited as an area of need. Respondents suggested that community leaders, in particular, had an important role to play in spearheading community education initiatives.

We suggest that we must meet and invite public speakers to talk about HIV and ARVs.

Churches must let people know about HIV and AIDS and ARVS. We could have dramas and songs on HIV/AIDS and ARVS.

Woman, Sekhukhune

The first thing that needs to be done is to educate the community, as they don't accept someone who is HIV-positive. With the present attitude, nothing can be done.

Person living with HIV, Maphumulo

Leaders in the community should call events where HIV-positive prominent people could be invited to disclose their status. This would really remove the stigma, as people tend to respect prominent people. We at community level should remove the notion that these HIV-positive people are bewitched and we ourselves should go out and test.

Community member, Sekhukhune

Sustained community support and positive attitudes to treatment and care was seen as important precursors to treatment uptake and adherence.

People are scared of HIV/AIDS so they [community members] can encourage people on treatment to take their treatment. They can do that because they avoid contracting HIV virus from that person. 
If we test frequently we shall be able to detect our status early. We as leaders of the community should test and set a good example.

Clinic committee member, Polokwane

They [community] should start to look around and assist home-based cares to look after other community members. This will create a healthy outlook towards issues around HIV and AIDS.

Person living with HIV, Sekhukhune

I think the community can play a role in supporting orphans that are living by themselves because of HIV/AIDS. There are children who don't have something to eat when they come back from school.

Social worker, Maphumulo

\section{Traditional healers}

Traditional healers were seen as having an important role to play in supporting and contributing to treatment and care.

Traditional healers and faith healers must be trained as counselors and have HIV test kits so that they could help those people who are not willing to go to hospitals. I think we also have to come with a plan of how we could work together with traditional leadership in area of HIV/AIDS.

Community leader, Maphumulo

\section{NGOS}

NGOs were seen as having the potential to greatly assist in treatment and care. A variety of roles and responsibilities for NGOs were recorded including treatment support and encouragement.

I think they [NGOs] should go house to house checking how people are doing in their homes. They have to advise people to come out so that they will able to get help. Now there is nobody who will laugh at them. People were scared to disclose because people were laugh at people who are HIV-positive. Mandela has talk about HIVIAIDS when his son was ill. This illness is like other illnesses. I don't know why people think that this illness is shameful.

Caregiver of child on ARVs, Chesterville

$N G O$ 's can help to advertise the importance of ARVs. There are still many people who need to be taught about ARVs treatment. I think NGO's can also support people on treatment by send people who will visit them in their houses and check if they take treatment. They can also check the person if s/he has enough support and enough food. They can also educate people because people still lack knowledge, which leads to the stigma.

Social worker, Maphumulo

The advantages of NGOs are that they are based in the communities and they deal direct with the sick people. If the government can form a forum with NGOs and distribute ARVs this would be helpful to people. There are sites that are very far from the community like places where people cross rivers if they going to hospitals. If there is NGO in that community the NGO can distribute ARVs to people and the caregivers can also help if they are well trained. It would be dangerous to provide ARVs while people are not well trained to monitor people on treatment. We would end up killing people with drugs.

NGO worker, Chesterville 
Respondents suggested that NGOs should play a role on educating communities on HIV, AIDS, and ARVs and that they should work with government to do this.

I think they [NGOs] should organize concerts in local shops or visit school and talk about HIV/AIDS. Most of NGO's are focused on children and gardens not to HIVIAIDS.

Person living with HIV, Maphumulo

The Home-based Carer program needs to be strengthened and knowledge on ARV needs to be spread by NGOs.

Home-based caregiver, Polokwane

I think NGO's should play important role because they are ones who have better access to communities. They monitoring people before people go to hospital. I think they need more training in terms how to work with people in terms of information and motivations.

Patient advocate, Maphumulo

We need NGOs in the community to be strengthened to monitor HIV individuals in the community.

Clinic staff, Polokwane

\section{Government departments}

Respondents suggested that government departments play a key role in providing education on HIV, AIDS, and ARVs.

The government needs to aggressively teach people to test early so that help could be received in time.

Woman, Polokwane

We need more health workers in our area to come and teach us about HIV/AIDS, as the death rate due to this is very high. Young people should be given special training as they seem to be infected more. The problem is that they hide the disease.

Community member, Maphumulo

Workshops are required to teach us on ARVs. Government workers disappoint us as they promise to come and they don't so they should give us more attention.

Community member, Maphumulo

Respondents also indicated that the government should offer nutritional support to people living with HIV, and that it should create and support income-generating projects.

Presently NGOs assist a lot with food parcels Home-based carer and education and I think these areas need to be strengthened, as NGOs are able to deal with problems that exist within the community. The Department of Health needs to work closely with NGOs.'

Social Worker, Sekhukhune

Government must assist us. We need projects that will assist HIV-positive people with an income. Things such as handicrafts and sewing will be appropriate for us, as we need an income to eat well and to lead a healthy life. Communal gardens would be helpful.

Person living with HIV not on ARVs, Maphumulo 
The Department of Agriculture could also assist with vegetable gardens. More community health workers should be recruited to assist people at community level. NGOs should assist with educations and work with government to facilitate what I have just said.

Person living with HIV, Maphumulo

Finally, the inaccessibility of services due to distance and travel costs led many to suggest that the government should provide treatment at local levels. In addition, they indicated that the government should facilitate and support local initiatives.

We think it would be better if services could be brought nearer to the community like in clinics, as the process of going to the hospital is very expensive.

Person living with HIV, Sekhukhune

Mobile clinics should go inside the communities and educate people about HIV/AIDS. They must also provide VCT because people are sick and they don't have money to come here to hospital.

ARV class, Maphumulo

The government should help us to form support groups. They should help us and teach us so that we are able to teach people and collect HIV-positive people at household level. You see we have got all the time to do that as most of us don't work and we are willing to do this therefore we need the government to empower us to be able to carry this task out. The idea being to break the silence and the stigma of HIV.

Person living with HIV, Sekhukhune 


\section{CONCLUSIONS}

The survey found that people in general were well informed on the scientific conception of HIV and AIDS, suggesting that AIDS awareness and prevention programmes in these communities have had some success. However, the prevalence of conflicting traditional and religious beliefs still pose a problem to public health care and, as a consequence, to public health.

Posters and other forms of written educational material have had limited impact due to illiteracy levels, their unavailability in local languages, and the one- dimensional nature of such materials. Faceto-face education predominantly takes place at health centres and accrues to people already within the broader health system, as opposed to reaching people who are not accessing services.

The data indicate that traditional healers play a significant role in the social topography of community life and can potentially play equally a significant role in the management of HIV and AIDS and reduction of stigma. They are perceived as credible sources of information and wield vast influence over their clientele. Traditional healers have a potential role to play in alleviating the current human resources crisis in the public health sector and in contributing to providing a seamless continuum of care for people with HIV and AIDS. The cooperation exhibited between traditional healers and western practitioners in some instances is encouraging.

There appear to be a variety of barriers to openly discussing youth sexuality, which has the effect of perpetuating myths and misinformation among youth that work directly in opposition to mainstream educational and awareness raising efforts. Disapproving attitudes from parent and adults toward youth sexuality compound the problem and create a climate of distrust and suspicion which is not conducive to facilitating youth access to treatment care and support services and information. Substance abuse appears to be a catalyst for engaging in unsafe sex practices and was reported to be widespread in all sites.

Women experience the epidemic differently from men and despite appearing to access health services more than men, bear a disproportionate burden of the consequences of HIV and AIDS. Entrenched patriarchy and poor socioeconomic conditions make them particularly vulnerable to infection. Transactional sex, often as a result of poverty implies that women do not have the power to negotiate the use of condoms with partners. Gender-based violence contributes to the spread of the epidemic.

Unaffordable transport or the lack of transport is a strong deciding factor in people's uptake of health services in general. These constraints take on a stronger resonance in the context of ARV provision, as regular trips are required to collect medication and to comply with medical check-ups. The use of money lenders has the effect of further impoverishing people due to being locked in cycles of debt as a result of exorbitant interest rates. Additionally, the non-financial costs associated with accessing health services together with unaffordable transport costs constitute a formidable barrier to accessing ARV treatment.

The research suggests that even after people have made the decision to seek treatment, the road to obtaining treatment is long and winding. The protracted enrolment process and eligibility criteria mean that many are unable to access treatment. As a result patients may voluntarily drop out of the program, fall through the cracks, or die before they can access treatment. The use of eligibility criteria is clearly a necessary part of prioritising access to treatment and allocation of scarce resources; however such arrangements may have the undesired effect of deterring people from seeking services.

For many people living with HIV, lack of food was associated with poor adherence to treatment. Additional nutritional support beyond counseling and education was limited in all four sites. Although people living with HIV reported receiving limited support from government departments and NGOs 
and CBOs in their communities, little long term and regular support seems to be offered. Supplements and immune boosters, widely used by people living with HIV, sometimes served as an alternative to ARVs.

Support groups are widely held to be beneficial in assisting people living with HIV cope with the disease. However, there are challenges to establishing support groups, retaining members, and sustaining groups over time in areas where resources are limited and the disease remains highly stigmatised. Support groups may also play an important role as an entry point for receiving other services including treatment and in promoting and supporting disclosure. They could also play an important role in promoting adherence through providing information, linking people living with HIV to services, addressing fears about ARVs, and providing access to positive role models of adherence.

Home-based care programmes are a main source of care and support for people living with HIV and their families. Levels of training are varied and remuneration scales remain uneven and dependent on irregular donor and government funding. In some cases, the caregivers in this sector are purely volunteers and are people living with HIV themselves who face the same challenges as the people they assist.

The community health worker system in South Africa can be strengthened. This cadre of worker was intended to play a significant role in the rollout of treatment and care for people living with HIV, however, there have been challenges regarding role confusion, lack of training, relationships with NGOs, health facilities, and home-based caregivers. Given the large catchment areas they serve, CHWs were sometimes seen as the only source of support for people living with HIV and at others as non-existent.

Clinic committees, legislated in the National Health Act, are a strategic entry point in developing community participation in health care services and HIV and AIDS issues in particular. However, clinic committees have not flourished and there is a wide range of opinions on their roles and functions. Where functional, they have played a significant role in education on HIV and AIDS and facilitating dialogue between the community and health centre.

While community involvement is widely promoted as an effective and feasible mechanism of improving health care delivery, operationalising community involvement remains a challenge. Previous negative and failed experiences of community initiatives may make people reluctant to support or participate in community involvement. Furthermore, households already in poverty may not have the resources, interest, or energy to invest. Despite its prominence in policy and legislative documents, few resources are actually allocated to support community participation.

Sustained gains in broadening access to treatment and care are likely to remain elusive without the full support and participation of communities. The study highlighted the need for communities, NGOs, and government departments to play a more active role in education of communities, treatment support and care, nutritional support, and income generating projects. 


\section{RECOMMENDATIONS}

In order to generate recommendations, respondents were asked about potential strategies various role players could employ to address the barriers to the ARV rollout identified. Participants identified a range of actions the government, NGOs and other community organizations, health facilities, and other community actors could take to address the community and facility-level barriers preventing the uptake and use of HIV related services. Recommendations were then developed from the participant feedback, as well as from trends identified by the researchers in the study findings. While the recommendations are based on the experiences of the four study sites, many of the strategies have wider applicability at both the policy and program level. Here key recommendations are presented by cluster.

\section{Cluster One: Barriers at the Community Level}

Because of high levels of illiteracy and misconceptions, messages contained in posters and pamphlets must be augmented by in-depth discussions about HIV and AIDS at the community level. The use of respected community stakeholders to deliver messages about HIV and AIDS in a wide range of contexts should be explored.

Raising awareness of the existence of stigma in the community, explaining its causes, and the various forms in which it is manifested is crucial to reducing it presence. People living with HIV and AIDS have an important role to play in encouraging disclosure, reducing stigma, and serving as trustworthy sources of information and positive role models for communities. Responsible and sustained political leadership and direction is also needed.

NGOs and CBOs have a crucial role to play in providing information and training on ARVs. Target audiences include the broader community, traditional healers, health facility workers, religious and traditional leaders, and local organizations such as women or youth groups. Training should include information on treatment centers, eligibility criteria, adherence, side effects, and healthy living.

Strategies to address high-risk behaviour among youth must be developed. Forums and groups for youth to discuss their sexuality, among themselves and with their parents and other community members, in a safe non-judgmental environment must be created and sustained. This is especially needed in rural areas where social taboos prevent such discussions. Counseling and rehabilitation services for youth to curb alcohol and substance abuse are also needed.

Educational activities need to be scaled up in order to address traditional beliefs that prevent people from seeking appropriate medical interventions for urgent health problems. Collaboration between traditional healers and Western medical practitioners is increasing and should be further promoted. Traditional healers must receive training and information on HIV and its management, and ways to encourage partnerships between the two health systems need to be explored.

Community-based organizations and NGOs have an important role to play in facilitating access to social security grants at the local level. CBOs and NGOs can act as a bridge between government departments, such as the Department of Home Affairs and Department of Social Development, and lobby for speedy processing of applications and the acceptance of alternative means of identification when applicants have difficulty providing the required documentation.

Poverty alleviation and food security programmes that target women should be developed to reduce their dependence on men and subsequent vulnerability to infection. Aggressive, culturally acceptable 
gender awareness programmes must be carried out at local levels in order to dispel many of the myths that perpetuate gender-based violence and discrimination against women.

\section{Cluster Two: Barriers at the Facility Level}

Plans must be made to fast track the delivery of ARVs at the primary clinic level. Districts must ensure that NGOs and CBOs are involved in the delivery of treatment at community level. Community level meetings to discuss how best to ensure collaboration between the health service, community and NGOs and CBOs are recommended to inform the process of greater involvement by the community and NGOs.

Attention must be paid to investigating and developing models of care that allow for maximum uptake of services and delivery of quality care. Issues for consideration should include exploring alternative models of providing VCT including using different locations and providers. VCT should be more aggressively promoted at community level. Effort must be placed on destigmatising current treatment sites and on providing treatment in a confidential and efficient manner.

An information system that tracks the number of people who have taken steps to access treatment would assist policy makers and program managers to improve services and advocate for resources. Research to explore where services can be decentralized, for example, conducting adherence training at community level, would assist to increase access to treatment services. Alternative methods of collecting medication should be explored. These included the appointment of procurators to collect medication or the introduction of a barcode system that would enable patients to collect their medication wherever they found convenient.

\section{Cluster Three: Experiences of People Living with HIV and AIDS}

Efforts are needed to support those caring for affected people. Stakeholders recommended that education activities need to also focus on family members as caregivers for those affected by the disease, as this would assist in destigmatising HIV and AIDS, capacitate caregivers to provide care and support, and increase community support for people living with HIV. Efforts to increase access to treatment will also eventually reduce the burden on caregivers if more HIV-positive people remain well and able to care for themselves.

Many organisations have advocated for greater access to social support for people living with HIV. Supporting this call could have numerous benefits for increasing access to treatment and promoting adherence and the well being of people living with HIV. In addition to employment creation efforts, the South African Government may have to explore mechanisms to increase social support to people living with HIV including less stringent eligibility criteria, if access to HIV related services and treatment are to be promoted and optimal treatment outcomes are to be achieved.

Additionally, health facilities may need to explore ways in which to reduce the cost of adhering for people living with HIV and their supporters in order to reduce treatment defaulting through lack of resources. Possible strategies in this regard include decentralizing the provision of services such as medication collection and adherence training. Advocacy for increased resources to provide community-based treatment support may also increase adherence. In situations where people living with HIV have not disclosed to community and family members beyond a treatment supporter, innovative mechanisms need to be developed and tested to increase adherence.

More needs to be done to establish the efficacy of immune boosters and other nutritional supplements. In addition, a cost-benefit analysis of the usefulness of various commercially available products may 
assist people living with HIV in deciding how best to use their limited resources. Strategies to reduce the cost of commercially available supplements may be needed if they are efficacious in improving the immune status of people. Advocacy, bulk purchasing, buying direct from suppliers, and other options need to be explored.

Given the South African Government's endorsement of the use of traditional medications, more effort needs to be invested in establishing the benefits and risks of the use of these products. The government may need to regulate the sale and use of these supplements. An unintended consequence of the current information strategies on adherence may be to discourage people from taking ARVs. A balance needs to be found between promoting ARVs and informing people of the potential dangers and side effects of treatment. Strategies to increase treatment promotion and support may address this gap.

There is a need to strengthen PMTCT programs including addressing issues around infant feeding, HIV diagnosis in infants and the follow up of women after PMTCT. Treating mothers may also assist in ensuring that HIV-positive children remain in the system and are treated if necessary. Ongoing efforts to enrol children on ARVs are needed in the South African context, particularly in rural areas and in lower prevalence provinces. Better links between HBC and OVC programs and treatment programs are also needed.

Strategies are needed to increase the accessibility and uptake of support group services. Successful models should be documented and disseminated. Alternative locations for support groups may increase the uptake of services. Similarly, linking support groups to the distribution of food parcels and income-generating activities may also increase their uptake and make them more sustainable. The role of support groups in promoting adherence needs to be explored further.

\section{Cluster Four: Role and Capacity of Community Organizations}

The existing role confusion between home-based caregivers and community health workers must be clarified to reduce unrealistic expectations from clients, NGOs, and health facility staff. Adequate mechanisms for effective and equitable distribution of community-based resources (food parcels, home-based care kits, stipends) must be found. While overarching frameworks would be useful for the purposes of standardization, these are not always appropriate or acceptable to communities. Discussions regarding roles and responsibilities should preferably take place at the community level, together with local health facility staff.

Attention must be paid to developing clinic committees in a manner that is realistic and sustainable. NGOs have a vital role to play in developing the capacity and skills of clinic committee members. Health care workers and other key players should be made aware of the benefits and role of clinic committees.

Steps to facilitate community involvement in HIV and AIDS services must be locally driven. NGOs have a role to play in assisting communities to identify their strengths and available resources as well as areas of need. Upstream, resources need to be allocated to drive the process. Transparent and credible mechanisms such as forums for dialogue and discussion between stakeholders and role players must be created at the local level. Successful models of community involvement must be disseminated and popularized. 


\section{REFERENCES}

Blecher, M. et al. (eds.). 2005. South African Health Review 2003-4. Durban: Health Systems Trust.

Day, C. and A. Gray. 2005. "Indicators" in P. Ijumba and P. Barron (eds.) South African Health Review 2005. Durban: Health Systems Trust.

Declaration of Alma-Ata. International Conference on Primary Health Care. Alma-Ata, USSR, 6-12 September 1978. Available at: http://www.who.int/hpr/ NPH/docs/declaration_almaata.pdf

Department of Health, Republic of South Africa. 2006. "Republic of South Africa: Progress report on declaration of commitment on HIV and AIDS," prepared for: United Nations General Assembly Special Session on HIV and AIDS. Pretoria: Department of Health.

Gaffney, P. (ed.). 2005. Gaffney's Local Government in South Africa 2004-2006. Johannesburg: Gaffney Group.

Farmer, P., et al. 2001. "Community-based approaches to HIV treatment in resource-poor settings," Lancet 358(9279): 404-9.

Grubb, I., J. Perriëns, and B.A. Schwartländer. 2003. "Public health approach to antiretroviral treatment: overcoming constraints," Perspectives and Practice in Antiretroviral Treatment. Geneva: World Health Organization.

International HIV/AIDS Alliance. 2002. "“Voices from the community': Report of a community consultation on antiretroviral treatment in Zambia." Brighton, UK: International HIV/AIDS Alliance: Zambia.

Joint Civil Society Monitoring Forum (JCSMF). 2006. "Resolutions of the 7th meeting of the JCSMF," minutes from $7^{\text {th }}$ meeting of JCSMF in Orkney, North West, South Africa, 3 March.

Loewenson, R. 2000. "Putting your money where your mouth is: Participation in mobilising and allocating health resources," paper presented at TARSC/Equinet regional meeting on Public Participation in Health, Harare, Zimbabwe, May.

Mbewu, A. et al. 2003. "Operational plan for comprehensive HIV and AIDS care, management and treatment for South Africa.” Johannesburg: South African Department of Health.

Mohamed, S.I. 2002. "The four townships survey (4TS)." Durban, South Africa: Organisation of Civic Rights.

Muhe, L. 2002. "Community involvement in rolling back malaria." Geneva: WHO.

"Ottawa charter for health promotion: First international conference on health promotion, Ottawa, Canada, 17-21 November 1986." 1986. Geneva: World Health Organization.

Phiri, S.N., G. Foster, and M. Nzima. 2001. "Expanding and strengthening community action: A study of ways to scale up community mobilization interventions to mitigate the effect of HIV/AIDS on children and families." Washington, DC: Displaced Children's and Orphans Fund.

Pitre, Amita. 2001. "Waking up the System," Humanscape 8(9): 8-10. 
Shisana, O. et al. 2005. South African National HIV Prevalence, HIV Incidence, Behaviour and Communication Survey, 2005. Cape Town: Human Sciences Research Council.

Statistics South Africa. 1996. Census 1996. Pretoria: Statistics South Africa.

—2001. Census 2001. Pretoria: Statistics South Africa.

van Praag, E. 2002. "Planning the incorporation on antiretroviral therapy into comprehensive care programmes." Geneva: UNAIDS.

WHO. 2004. "Chapter 3: Community participation: advocacy and action," in The World Health Report 2004: Changing History. Geneva: WHO.

WHO/UNAIDS. 2004. "Emergency scale-up of ART in resource-limited settings: technical and operational recommendations to achieve ' 3 by 5 '." Geneva: WHO. 


\section{Appendix: Overview of Study Sites}

\section{Kwazulu Natal Province}

With a population of approximately 9.5 million people, KwaZulu Natal (KZN) has the highest population density in South Africa after Gauteng province and the largest share of the country's population (Gaffney 2005). Little more than half of the population lives in a rural environment, including commercial farms, small settlements, rural villages, and other areas that are further away from towns and cities (Statistics South Africa 1996). The annual per capita income is R11.000 (Gaffney 2005) and over 21 percent of people over the age of 20 have had any education (Day et al 2005). The overall unemployment rate (official definition) in the province in 2004 was 32 percent (Day et al. 2005). Nearly 90 percent of the population has no access to private medical schemes and is therefore dependent on the public health sector (Blecher 2005).

In 2002, life expectancy at birth was 47.5 years and infant mortality was 68 per 1,000 live births. In 2004, the province's HIV prevalence among pregnant women at antenatal screening sites was 40.7, ranking highest in South Africa. With more than 120,000 AIDS orphans (maternal) in 2002, the province has the highest number of AIDS orphans in the country (Day et al. 2005).

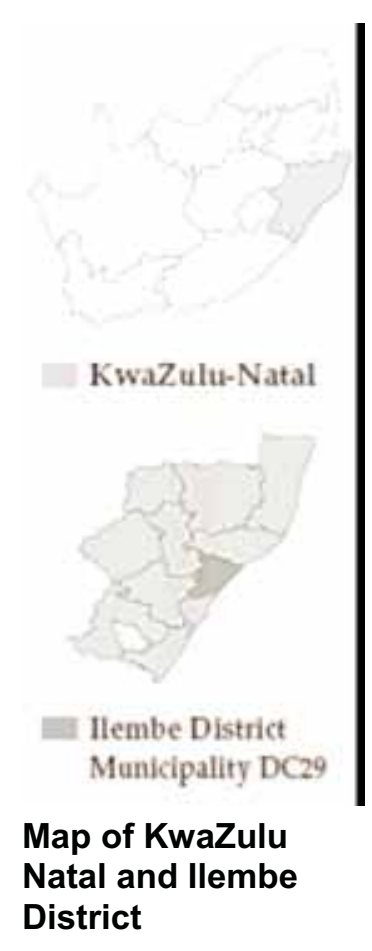

\begin{abstract}
Maphumulo
Maphumulo municipality is part of the Ilembe district, one of the 10 districts in KwaZulu Natal province. The municipality is comprised of 11 wards and houses a population of 120,642 people (Gaffney 2005).

The major characteristic of the municipality is its predominantly rural character-tribal land administered by a trust on behalf of local communities. As in many parts of KwaZulu Natal, sugar cane cultivation is the predominant economic activity. Land usage is dominated by subsistence agricultural activities carried out by traditional family units (Gaffney 2005).

The linkage to the N2 motorway is vital as it provides for migrant labour transport as well as access to commercial and employment markets in the Durban Metro and other cities. Infrastructure is poor; tertiary roads are not surfaced and traverse steep terrain, limiting access in poor weather. The economic base of the municipality is comprised of the service industry, farming, and remittances from people working elsewhere. There is little or no economic regeneration. The area is served by two basic care hospitals in two wards, and six clinics spread over the area. Three wards do not have any health care facilities (Gaffney 2005).
\end{abstract}

Housing in the Municipality consists largely of traditional rural dwellings, and a substantial number of households live in formal housing.

Thirteen percent of Maphumulo's population has received some primary schooling, 4.4 percent completed primary school, 9.3 percent had some secondary education and 2.9 percent finished matric. (Gaffney 2005).

\footnotetext{
${ }^{1}$ Approximately $\$ 1,833$ at R6 to $\$ 1$.
} 
Seven percent of the labour force is formally employed, 22 percent is unemployed and 71 percent of the population is not economically active at all. Those who do have employment work mostly in agriculture, in/for the community, in private households, or in wholesale/retail (Gaffney 2005).

Fifty-three percent of households have a monthly income lower than R1,600, whereas 37 percent of households receive no formal income at all (Gaffney 2005).

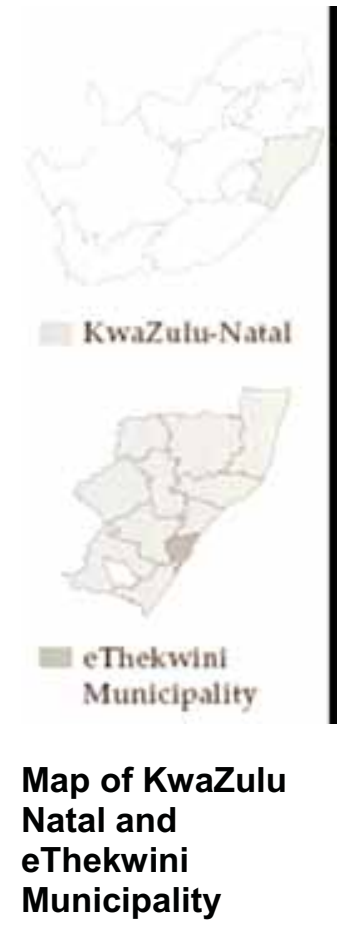

\section{Chesterville}

The Durban Metropolitan Area (DMA) is experiencing rapid population growth rate due to increasing urbanisation, natural growth and migration. This coupled with large-scale unemployment, poverty, and poor service provision is causing the population of the DMA to impact negatively on the natural environment.

Chesterville was built as a township during the apartheid era to provide housing for Africans. The area has a population of 25,000 people (Statistics South Africa 2001) and is still predominantly populated by Africans. The residential area has a 64 percent formal unemployment rate and the majority of people earn between R500 and R1,300 a month. Eighty-four percent of households had a total monthly income of less than R1,300 (Mohamed 2002).

Chesterville consists mainly of formal houses and household sizes vary from two to eight family members (Statistics South Africa 2001).

\section{Limpopo Province}

With a population of 5,273,642 people, Limpopo is inhabited by 11.8 percent of the South African population. At the time of the census in 2001, 87 percent of these people lived in rural areas, which makes it by far the most "rural" province in the country. As many people cannot afford medical aid, 93 percent of the population is dependent on the public health sector for their health needs (Blecher 2005).

About one third of those aged 20 years or older have not received any schooling (Day et al. 2005). Limpopo's education level is thereby the lowest in the country.

In 2004, the unemployment rate (official definition) in the province was 30 percent (Day et al. 2005).

Life expectancy, as estimated in 2002, was 54.4 and infant mortality in the province was 53 per 1000 live births (Day et al. 2005).

In contrast with the low development statistics, the antenatal HIV prevalence was 19 percent in 2004 (Day et al. 2005) the lowest in the country, after the Northern Cape and Western Cape. 


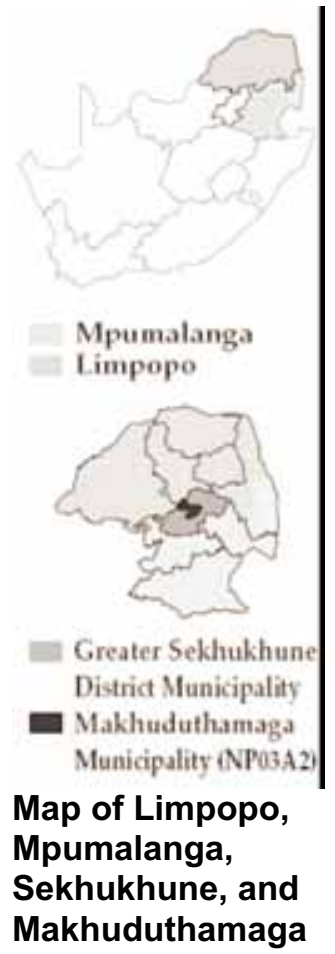

Sekhukhune and Makhuduthamaga

Sekhukhune falls under the Makhuduthamaga local municipality and contributes to the Greater Sekhukhune District Municipality. Its population of 262,903 people are predominantly African.

Makhuduthamaga is a rural local municipality, which, as a result of apartheid policies, has for a long time been deprived of access to basic services. There are 146 settlements spread over 31 wards. Nearly 80 percent of households have formal housing, and a substantial number of households live in traditional dwellings. The area has many traditional authorities with a 100 percent African population. The majority of communities live in poverty, their income being constrained by a rural economy that is unable to provide them with remunerative jobs or self-employment opportunities. The informal sector plays a significant role in gaining a living. A large proportion of the population has no elementary education, 14 percent had some primary education and only 13 percent had some secondary education (Gaffney 2005).

Access to health facilities in the district is poor. There is one clinic for every 17,000 people. The municipality has 3 hospitals, 13 clinics, and 2 mobile clinics (Gaffney 2005).

Drought is a serious problem in the region, and availability of ground water is very limited. The backlog in sanitation and electricity provision is also considerable. Infrastructure is impaired; due to financial constraints the maintenance of especially gravel roads is poor (Gaffney 2005).

Eight percent of the labour force is employed, 24 percent is unemployed, and 68 percent is not economically active at all. Employment for the community is mostly in the areas of construction, private households, transport/communication or wholesale/retail (Gaffney 2005).

Forty-eight percent of the households earn an income of less than R1.600 per month, while 42 percent of the households have no formal income at all (Gaffney 2005).

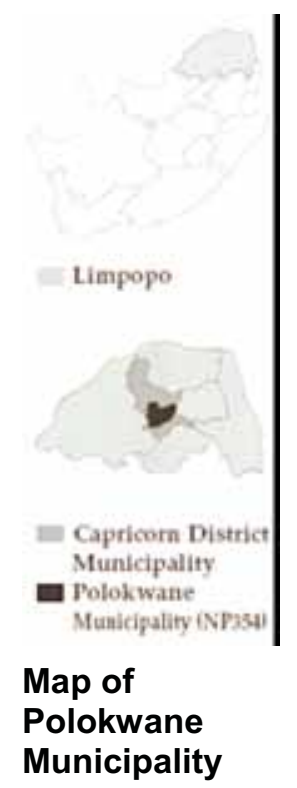

\section{Polokwane}

Polokwane is the capital of Limpopo Province, and its commercial, financial, industrial, educational and administrative centre. Divided in 37 wards, it contributes to the Capricorn District Municipality in Limpopo province. It has a total population of 508,277 people, 92 percent of whom are African, 6 percent are white and the remaining are Coloured and Indian. Polokwane is strategically located being a major centre near the neighbouring countries of Botswana, Zimbabwe, Mozambique, and Swaziland (Gaffney 2005).

In terms of education, 5 percent completed only primary school, and 9 percent completed matric. Four percent went to a tertiary education institution (Gaffney 2005).

A majority of 80 percent households live in formal housing, and still a very large number (16 percent) live in informal settlements (Gaffney 2005). 
The population in Polokwane has an unemployment rate of 22 percent, while 47 percent of people are not economically active at all. Those who are employed (31 percent) work in/for the community, in private households, or in other sectors like financial/insurance/real estate/business, manufacturing, or wholesale/retail (Gaffney 2005).

Sixty-six percent of households have a monthly income of R3,200 and 24 percent have no formal income at all (Gaffney 2005).

For its health care, the area is served by 24 clinics, six mobile clinics, five public hospitals, and one private hospital (Gaffney 2005). 


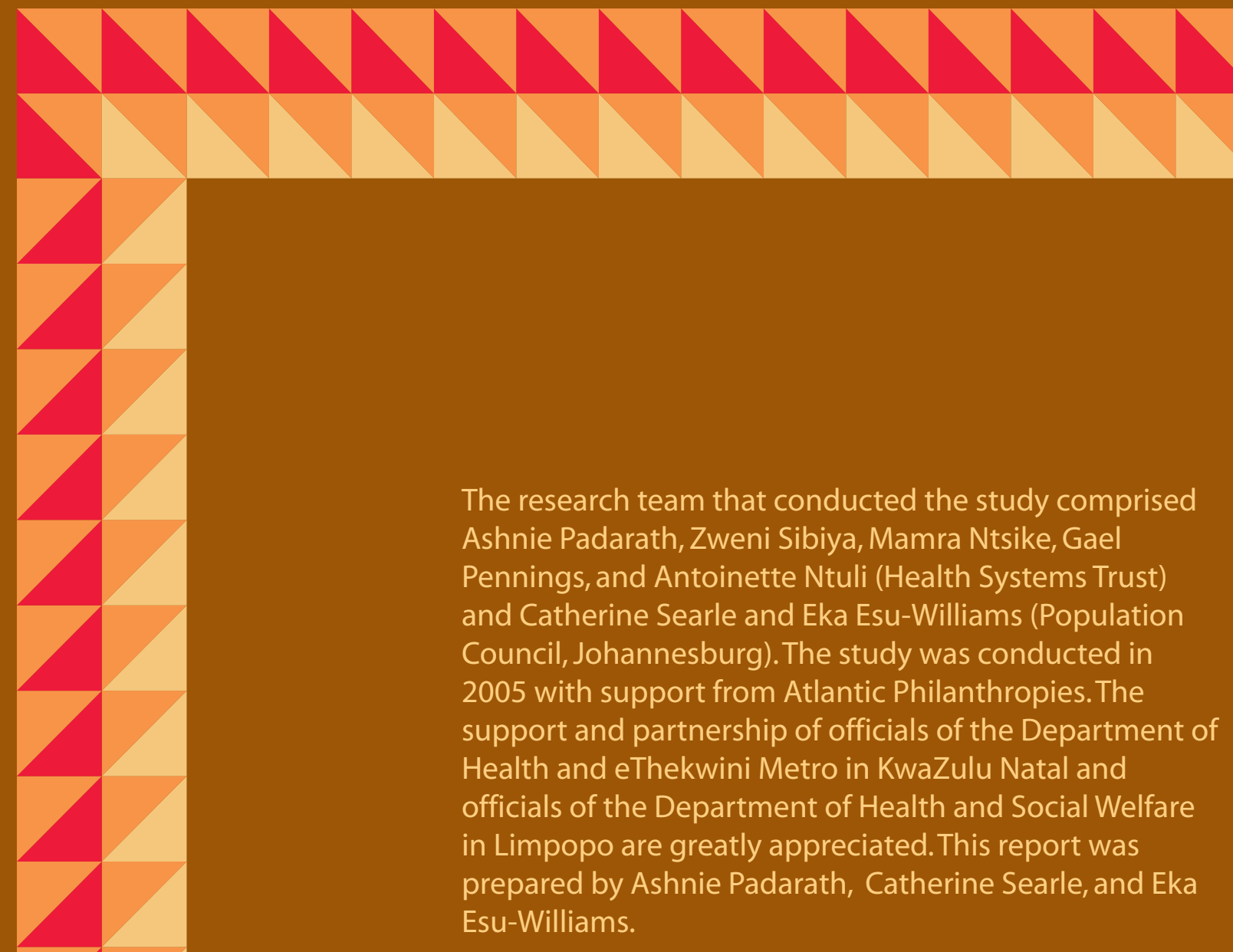

For further information please contact:

Population Council

Hurlingham Office Park, 1st Floor, Block D7

Cnr. William Nicol and Republic Road

Hurlingham

192 Dunkeld West, Johannesburg 2196

Tel No: 0114384400

Fax: 0117877371

Website: www.popcouncil.org 